\title{
The influence of ozone precursor emissions from four world regions on tropospheric composition and radiative climate forcing
}

\author{
Meridith M. Fry, ${ }^{1}$ Vaishali Naik, ${ }^{2}$ J. Jason West, ${ }^{1}$ M. Daniel Schwarzkopf, ${ }^{3}$ \\ Arlene M. Fiore, ${ }^{3,4}$ William J. Collins, ${ }^{5}$ Frank J. Dentener, ${ }^{6}$ Drew T. Shindell, ${ }^{7}$ \\ Cyndi Atherton, ${ }^{8,9}$ Daniel Bergmann, ${ }^{8}$ Bryan N. Duncan, ${ }^{10}$ Peter Hess, ${ }^{11}$ \\ Ian A. MacKenzie, ${ }^{12}$ Elina Marmer,${ }^{6,13}$ Martin G. Schultz, ${ }^{14}$ Sophie Szopa, ${ }^{15}$ \\ Oliver Wild, ${ }^{16}$ and Guang Zeng ${ }^{17}$
}

Received 8 November 2011; revised 23 February 2012; accepted 4 March 2012; published 13 April 2012.

[1] Ozone $\left(\mathrm{O}_{3}\right)$ precursor emissions influence regional and global climate and air quality through changes in tropospheric $\mathrm{O}_{3}$ and oxidants, which also influence methane $\left(\mathrm{CH}_{4}\right)$ and sulfate aerosols $\left(\mathrm{SO}_{4}^{2-}\right)$. We examine changes in the tropospheric composition of $\mathrm{O}_{3}$, $\mathrm{CH}_{4}, \mathrm{SO}_{4}^{2-}$ and global net radiative forcing (RF) for $20 \%$ reductions in global $\mathrm{CH}_{4}$ burden and in anthropogenic $\mathrm{O}_{3}$ precursor emissions $\left(\mathrm{NO}_{\mathrm{x}}, \mathrm{NMVOC}\right.$, and $\left.\mathrm{CO}\right)$ from four regions (East Asia, Europe and Northern Africa, North America, and South Asia) using the Task Force on Hemispheric Transport of Air Pollution Source-Receptor global chemical transport model (CTM) simulations, assessing uncertainty (mean \pm 1 standard deviation) across multiple CTMs. We evaluate steady state $\mathrm{O}_{3}$ responses, including long-term feedbacks via $\mathrm{CH}_{4}$. With a radiative transfer model that includes greenhouse gases and the aerosol direct effect, we find that regional $\mathrm{NO}_{\mathrm{x}}$ reductions produce global, annually averaged positive net RFs $\left(0.2 \pm 0.6\right.$ to $\left.1.7 \pm 2 \mathrm{mWm}^{-2} / \mathrm{Tg} \mathrm{N} \mathrm{yr}^{-1}\right)$, with some variation among models. Negative net RFs result from reductions in global $\mathrm{CH}_{4}\left(-162.6 \pm 2 \mathrm{mWm}^{-2}\right.$ for a change from 1760 to $\left.1408 \mathrm{ppbv} \mathrm{CH}_{4}\right)$ and regional NMVOC $\left(-0.4 \pm 0.2\right.$ to $\left.-0.7 \pm 0.2 \mathrm{mWm}^{-2} / \mathrm{Tg} \mathrm{C} \mathrm{yr}^{-1}\right)$ and $\mathrm{CO}$ emissions $\left(-0.13 \pm 0.02\right.$ to $\left.-0.15 \pm 0.02 \mathrm{mWm}^{-2} / \mathrm{Tg} \mathrm{CO} \mathrm{yr}^{-1}\right)$. Including the effect of $\mathrm{O}_{3}$ on $\mathrm{CO}_{2}$ uptake by vegetation likely makes these net RFs more negative by -1.9 to $-5.2 \mathrm{mWm}^{-2} / \mathrm{Tg} \mathrm{N} \mathrm{yr}^{-1},-0.2$ to $-0.7 \mathrm{mWm}^{-2} / \mathrm{Tg} \mathrm{C} \mathrm{yr}^{-1}$, and -0.02 to $-0.05 \mathrm{mWm}^{-2}$ /

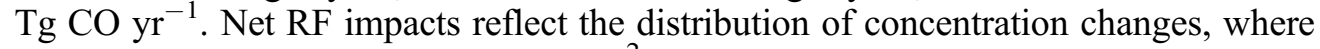
$\mathrm{RF}$ is affected locally by changes in $\mathrm{SO}_{4}^{2-}$, regionally to hemispherically by $\mathrm{O}_{3}$, and globally by $\mathrm{CH}_{4}$. Global annual average $\mathrm{SO}_{4}^{2-}$ responses to oxidant changes range from $0.4 \pm 2.6$ to $-1.9 \pm 1.3 \mathrm{Gg}$ for $\mathrm{NO}_{\mathrm{x}}$ reductions, $0.1 \pm 1.2$ to $-0.9 \pm 0.8 \mathrm{Gg}$ for NMVOC reductions, and $-0.09 \pm 0.5$ to $-0.9 \pm 0.8 \mathrm{Gg}$ for $\mathrm{CO}$ reductions, suggesting additional research is needed. The 100 -year global warming potentials $\left(\mathrm{GWP}_{100}\right)$ are calculated for the global $\mathrm{CH}_{4}$ reduction $\left(20.9 \pm 3.7\right.$ without stratospheric $\mathrm{O}_{3}$ or water vapor, $24.2 \pm 4.2$ including those components), and for the regional $\mathrm{NO}_{\mathrm{x}}, \mathrm{NMVOC}$, and $\mathrm{CO}$ reductions $\left(-18.7 \pm 25.9\right.$ to $-1.9 \pm 8.7$ for $\mathrm{NO}_{\mathrm{x}}, 4.8 \pm 1.7$ to $8.3 \pm 1.9$ for NMVOC, and $1.5 \pm 0.4$ to $1.7 \pm 0.5$ for $\mathrm{CO}$ ). Variation in $\mathrm{GWP}_{100}$ for $\mathrm{NO}_{\mathrm{x}}, \mathrm{NMVOC}$, and $\mathrm{CO}$ suggests that regionally specific GWPs may be necessary and could support the inclusion

\footnotetext{
${ }^{1}$ Department of Environmental Sciences and Engineering, University of North Carolina at Chapel Hill, Chapel Hill, North Carolina, USA.

${ }^{2}$ Atmospheric Physics, Chemistry, and Climate Group, UCAR GFDL, Princeton, New Jersey, USA.

${ }^{3}$ Atmospheric Physics, Chemistry, and Climate Group, NOAA GFDL, Princeton, New Jersey, USA.

${ }^{4}$ Now at Lamont-Doherty Earth Observatory, Palisades, New York, USA.

${ }^{5}$ Met Office Hadley Centre, Exeter, UK.

${ }^{6}$ Institute for Environment and Sustainability, DG-Joint Research Centre, European Commission, Ispra, Italy.

${ }^{7}$ NASA Goddard Institute for Space Studies, New York, New York, USA.

Copyright 2012 by the American Geophysical Union. 0148-0227/12/2011JD017134
}

\footnotetext{
${ }^{8}$ Atmospheric Earth and Energy Division, Lawrence Livermore National Laboratory, Livermore, California, USA.

${ }^{9}$ Now at Gordon and Betty Moore Foundation, Palo Alto, California, USA.

${ }^{10}$ NASA Goddard Space Flight Center, Greenbelt, Maryland, USA.

${ }^{11}$ Biological and Environmental Engineering, Cornell University, Ithaca, New York, USA.

${ }^{12}$ School of GeoSciences, University of Edinburgh, Edinburgh, UK.

${ }^{13}$ Now at Department of Geography, University of Hamburg, Hamburg, Germany.

${ }^{14}$ Institut für Energie- und Klimaforschung (IEK-8), Forschungszentrum Jülich GmbH, Jülich, Germany.

${ }^{15}$ Laboratoire des Sciences du Climat et de l'Environnement, CEA, IPSL, UVSQ, CNRS, Gif-sur-Yvette, France.

${ }^{16}$ Lancaster Environment Centre, Lancaster University, Lancaster, UK.

${ }^{17}$ National Institute of Water and Atmospheric Research, Lauder, New Zealand.
} 
of $\mathrm{O}_{3}$ precursors in future policies that address air quality and climate change simultaneously.

Both global net RF and $\mathrm{GWP}_{100}$ are more sensitive to $\mathrm{NO}_{\mathrm{x}}$ and NMVOC reductions

from South Asia than the other three regions.

Citation: Fry, M. M., et al. (2012), The influence of ozone precursor emissions from four world regions on tropospheric composition and radiative climate forcing, J. Geophys. Res., 117, D07306, doi:10.1029/2011JD017134.

\section{Introduction}

[2] Tropospheric ozone $\left(\mathrm{O}_{3}\right)$, methane $\left(\mathrm{CH}_{4}\right)$, and aerosols make important contributions to the global mean radiative forcing (RF) of climate [Forster et al., 2007; Ramaswamy et al., 2001]. Here we aim to quantify the net RF of these species due to regional changes in $\mathrm{O}_{3}$ precursor emissions, across an ensemble of global chemical transport models (CTMs). We define net RF as the net (incoming minus outgoing) change in irradiance (solar and infrared) at the tropopause between a base and perturbed state (in Watts per square meter $\left[\mathrm{W} \mathrm{m}^{-2}\right]$ ) after allowing stratospheric temperatures to readjust [Forster et al., 2007]. The contribution of changes in tropospheric $\mathrm{O}_{3}$ to the global mean RF since preindustrial times is an estimated $0.35 \pm 0.15 \mathrm{Wm}^{-2}$, which is approximately $21 \%$ of the RF due to changes in carbon dioxide $\left(\mathrm{CO}_{2}\right)$ [Forster et al., 2007]. Changes in $\mathrm{CH}_{4}$ have contributed approximately $0.48 \mathrm{Wm}^{-2}$, while those in sulfate aerosols $\left(\mathrm{SO}_{4}^{2-}\right)$ have contributed approximately $-0.4 \pm 0.2 \mathrm{Wm}^{-2}$ (direct effect only) [Forster et al., 2007].

[3] Changes in $\mathrm{O}_{3}$ precursor emissions (nitrogen oxides $\left[\mathrm{NO}_{\mathrm{x}}\right]$, non-methane volatile organic compounds [NMVOC], carbon monoxide [CO], and $\mathrm{CH}_{4}$ ) affect the abundance of gaseous species $\left(\mathrm{O}_{3}\right.$ and $\left.\mathrm{CH}_{4}\right)$, and aerosols via changes in the availability of atmospheric oxidants (hydroxyl radical $[\mathrm{OH}]$, hydrogen peroxide $\left.\left[\mathrm{H}_{2} \mathrm{O}_{2}\right], \mathrm{O}_{3}\right)$ [Pham et al., 1995; Unger et al., 2006; Shindell et al., 2009; Leibensperger et al., 2011]. These perturbations in turn influence the RF due to $\mathrm{O}_{3}$ and $\mathrm{CH}_{4}$ and inorganic aerosol-phase species [Ming et al., 2005; Unger et al., 2006; Naik et al., 2007; Shindell et al., 2009]. $\mathrm{O}_{3}$ precursors also affect organic aerosols, including the formation of secondary organic aerosols (SOA) [Carlton et al., 2010], but the resulting RF remains to be quantified. $\mathrm{O}_{3}$ decreases plant growth and hence reduces the removal of $\mathrm{CO}_{2}$ from the atmosphere [Felzer et al., 2007; Sitch et al., 2007; Collins et al., 2010], while $\mathrm{NO}_{\mathrm{x}}$ emissions influence nitrogen deposition and the subsequent uptake of $\mathrm{CO}_{2}$ in terrestrial and oceanic ecosystems [Holland and Lamarque, 1997; Duce et al., 2008]. Because of these influences, actions to control $\mathrm{O}_{3}$ precursor emissions affect both air quality and global climate [Fiore et al., 2002; Dentener et al., 2005; West et al., 2007].

[4] Past studies have shown that both regional and global reductions in $\mathrm{NO}_{\mathrm{x}}$ surface emissions produce an overall positive $\mathrm{RF}$ from global $\mathrm{CH}_{4}$ increases via decreases in $\mathrm{OH}$, which outweigh the negative forcing from tropospheric $\mathrm{O}_{3}$ decreases. The magnitude of forcing, however, depends on the location or sector of emission reduction [Fuglestvedt et al., 1999; Wild et al., 2001; Berntsen et al., 2005; Naik et al., 2005; West et al., 2007; Derwent et al., 2008]. In contrast, $\mathrm{CO}, \mathrm{NMVOC}$, and $\mathrm{CH}_{4}$ reductions contribute an overall negative RF by decreasing tropospheric $\mathrm{O}_{3}$ and increasing $\mathrm{OH}$, leading to global $\mathrm{CH}_{4}$ decreases [Prather, 1996; Wild et al., 2001; Fiore et al., 2002; Naik et al., 2005]. Global anthropogenic $\mathrm{CH}_{4}$ emission reductions were shown to produce the most negative $\mathrm{RF}$ of the $\mathrm{O}_{3}$ precursors, mainly due to direct reductions in $\mathrm{CH}_{4}$ forcing [Fiore et al., 2002; Shindell et al., 2005; West et al., 2007].

[5] Because of the short atmospheric lifetimes of $\mathrm{O}_{3}$, aerosols, and their precursors (apart from $\mathrm{CH}_{4}$ ), studies of regional $\mathrm{O}_{3}$ precursor reductions show that air quality and RF effects depend strongly on the geographical location of emissions [Fuglestvedt et al., 1999; Berntsen et al., 2005; Naik et al., 2005]. The dependence on location, however, has made it difficult to include $\mathrm{O}_{3}$ precursors in emissions trading schemes or international climate agreements [Rypdal et al., 2005], and to evaluate the co-benefits of actions to reduce $\mathrm{O}_{3}$ for slowing global climate change. Studies have shown substantial dependence of $\mathrm{O}_{3}$ concentrations and RF on the region of $\mathrm{NO}_{\mathrm{x}}$ emissions [Fuglestvedt et al., 1999; Berntsen et al., 2005; Naik et al., 2005; Derwent et al., 2008; Fuglestvedt et al., 2010], where $\mathrm{O}_{3}$ and $\mathrm{RF}$ are more sensitive to $\mathrm{NO}_{\mathrm{x}}$ reductions from tropical regions, yet positive global annual average net RFs result from $\mathrm{NO}_{\mathrm{x}}$ reductions in each of nine world regions [Naik et al., 2005]. While NMVOCs typically have atmospheric lifetimes comparable to $\mathrm{NO}_{\mathrm{x}}, \mathrm{CO}$ has a longer atmospheric lifetime of 1-3 months [Seinfeld and Pandis, 2006], suggesting that the influence of $\mathrm{CO}$ on $\mathrm{O}_{3}$ and $\mathrm{OH}$ may be less dependent on reduction region [Berntsen et al., 2005; Rypdal et al., 2005]. Apart from Naik et al. [2005], who also examined combined reductions in $\mathrm{NO}_{\mathrm{x}}, \mathrm{CO}$, and NMVOCs from three regions, and Berntsen et al. [2005], who evaluated CO changes from two regions, less attention has been placed on regional $\mathrm{CO}$ and NMVOC emissions and their effects on tropospheric $\mathrm{O}_{3}$, $\mathrm{CH}_{4}$, and $\mathrm{SO}_{4}^{2-}$ and global and regional net RF. In response to nonuniform forcings, some regional climate responses are also sensitive to the location and distribution of $\mathrm{O}_{3}$, aerosols, and RF [Shindell and Faluvegi, 2009].

[6] Here we investigate the effects of a $20 \%$ reduction in global $\mathrm{CH}_{4}$ abundance and $20 \%$ reductions in anthropogenic emissions of $\mathrm{NO}_{\mathrm{x}}, \mathrm{NMVOC}$, and $\mathrm{CO}$, individually and combined, from four world regions on tropospheric $\mathrm{O}_{3}$, $\mathrm{CH}_{4}$, and $\mathrm{SO}_{4}^{2-}$ concentrations and on the resulting distribution and magnitude of global net RF for all precursorregion pairs. We use results from an ensemble of global CTMs that participated in the Task Force on Hemispheric Transport of Air Pollution (TF HTAP) multimodel intercomparison study of Source-Receptor (SR) sensitivity [Fiore et al., 2009], which allows for an assessment of uncertainty as the spread across CTMs. We examine the regional dependency of RF and global warming potential (GWP) to individual precursors by comparing estimates across the four regions of reduction.

\section{Methodology}

[7] We use the results from an ensemble of 11 global CTMs [Task Force on Hemispheric Transport of Air 
Table 1. HTAP Source-Receptor Sensitivity Simulations, Where the Four Regions of Reduction are East Asia, Europe, North America, and South Asia for SR3 Through SR6

\begin{tabular}{ll}
\hline Scenario & \multicolumn{1}{c}{ Description } \\
\hline SR1 & Base simulation \\
SR2 & $20 \%$ reduction in global $\mathrm{CH}_{4}$ \\
& mixing ratio \\
SR3 & $20 \%$ reduction in regional \\
& NO emissions \\
SR4 & $20 \%$ reduction in regional \\
& NMVOC emissions \\
SR5 & $20 \%$ reduction in regional \\
& CO emissions \\
SR6 & 20\% reduction in regional $\mathrm{NO}_{\mathrm{x}}$, \\
& NMVOC, CO, and aerosol emissions \\
\hline
\end{tabular}

Pollution, 2010] to evaluate changes in the tropospheric distributions of $\mathrm{O}_{3}, \mathrm{CH}_{4}$, and $\mathrm{SO}_{4}^{2-}$ for each reduction scenario. The net $\mathrm{RF}$ is calculated from the simulated changes in $\mathrm{O}_{3}, \mathrm{CH}_{4}$, and $\mathrm{SO}_{4}^{2-}$ using the standalone radiative transfer model (RTM) developed by the National Oceanographic and Atmospheric Administration (NOAA) Geophysical Fluid Dynamics Laboratory (GFDL) [Schwarzkopf and Ramaswamy, 1999; GFDL Global Atmospheric Model Development Team (GFDL GAMDT), 2004]. We estimate the RF due to $\mathrm{SO}_{4}^{2-}$, as $\mathrm{SO}_{4}^{2-}$ responds to oxidant changes, considering only its direct effects on radiation [Naik et al., 2007]; few CTMs reported other aerosol species for all reduction scenarios. Although we account for variability across the CTM ensemble in the $\mathrm{O}_{3}$, $\mathrm{SO}_{4}^{2-}$, and $\mathrm{CH}_{4}$ estimates, we likely underestimate the uncertainty in net RF by using only a single RTM.

\subsection{HTAP CTM Simulations}

[8] The SR simulations performed by each CTM are outlined in Table 1 . We analyze $\mathrm{O}_{3}$ and $\mathrm{CH}_{4}$ results from 11 CTMs and $\mathrm{SO}_{4}^{2-}$ results from four CTMs (Table 2). Each CTM utilized its own emissions inventory and prescribed meteorological fields for the year 2001 [Fiore et al., 2009]. Anthropogenic emissions of $\mathrm{NO}_{\mathrm{x}}$, NMVOCs, CO, and all precursors combined were reduced by $20 \%$ in each of four world regions: East Asia (EA), Europe and Northern Africa (EU), North America (NA), and South Asia (SA). For $\mathrm{CH}_{4}$, the present-day abundance (1760 parts per billion by volume [ppbv]) was imposed in all simulations except for the $\mathrm{CH}_{4}$

Table 2. Global CTMs Used for Multimodel Mean $\mathrm{O}_{3}, \mathrm{CH}_{4}$, and $\mathrm{SO}_{4}^{2-}$ Estimates

\begin{tabular}{ll}
\hline \multicolumn{1}{c}{ Model } & \multicolumn{1}{c}{ Institution } \\
\hline CAMCHEM-3311m13 & NCAR, USA \\
FRSGCUCI-v01 & Lancaster University, UK \\
GISS-PUCCINI-modelE & NASA GISS, USA \\
GMI-v02f & NASA GSFC, USA \\
INCA-vSSz & LSCE, France \\
LLNL-IMPACT-T5a a & LLNL, USA \\
MOZARTGFDL-v2 ${ }^{\mathrm{a}}$ & GFDL, USA \\
MOZECH-v16 & FZ Juelich, Germany \\
STOC-HadAM3-v01 & University of Edinburgh, UK \\
TM5-JRC-cy2-ipcc-v1 & JRC, Italy \\
UM-CAM-v01 & University of Cambridge, \\
& UK/NIWA, NZ \\
\hline
\end{tabular}

${ }^{\mathrm{a}}$ The four global CTMs used for multimodel mean $\mathrm{SO}_{4}^{2-}$ estimates. control simulation (SR2), where global $\mathrm{CH}_{4}$ abundance was decreased by $20 \%$ to 1408 ppbv. All simulations were performed for a full year (2001), after an initial spin-up of at least six months [Fiore et al., 2009].

[9] The multimodel mean \pm 1 standard deviation changes in the anthropogenic emissions of $\mathrm{NO}_{\mathrm{x}}, \mathrm{NMVOCs}$, and $\mathrm{CO}$, across 11 CTMs, are presented in Table 3. There is considerable variability in the emission reduction magnitudes across CTMs. Coefficients of variation (CVs) (standard deviation/mean) are lowest for $\mathrm{NO}_{\mathrm{x}}$ emissions from $\mathrm{EU}$, $\mathrm{NA}$, and SA, while there is more variability in NMVOC and $\mathrm{CO}$ emissions from the four regions, consistent with the comparison of current global emission inventories by Granier et al. [2011].

[10] Previous publications based on the HTAP SR experiments have emphasized the effects of long-range transport on surface $\mathrm{O}_{3}$, and other components, and comparisons with observations [Sanderson et al., 2008; Shindell et al., 2008; Fiore et al., 2009; Jonson et al., 2010; Reidmiller et al., 2009]. Fiore et al. [2009] found that the HTAP ensemble mean surface $\mathrm{O}_{3}$ concentrations compared well with observations over EU for the year 2001, but overestimated measurements by more than $10 \mathrm{ppb}$ during the summer and fall over the eastern United States and Japan. Jonson et al. [2010] compared simulated vertical $\mathrm{O}_{3}$ profiles with observed ozonesonde profiles, finding that the spread in CTM results (and their over and underestimation of $\mathrm{O}_{3}$ soundings) increases in the spring and summer with more active chemistry. In the winter and spring, seasonal averages for most CTMs were within $20 \%$ of sonde measurements in the upper and middle troposphere. Simulated $\mathrm{SO}_{4}^{2-}$ concentrations at the surface for the base simulation (SR1) also have been compared to observations (M. Schulz, personal communication, 2011, preliminary results available at http:// aerocom.met.no/cgi-bin/aerocom/surfobs annualrs.pl), where the results show that the CTMs are generally realistic.

[11] Short-lived $\mathrm{O}_{3}$ precursors affect tropospheric $\mathrm{O}_{3}$ within hours to weeks after their emission; however, they also affect $\mathrm{OH}$, which influences the lifetime of $\mathrm{CH}_{4}$ and in turn, $\mathrm{O}_{3}$ in the long term [Prather, 1996; Wild et al., 2001; Berntsen et al., 2005; Naik et al., 2005]. Global $\mathrm{CH}_{4}$ changes were calculated by Fiore et al. [2009], based on the $\mathrm{CH}_{4}$ loss by tropospheric $\mathrm{OH}$ diagnostic reported for each CTM and SR3 through SR6, relative to the fixed $\mathrm{CH}_{4}$ abundance of 1760 ppbv. Long-term $\mathrm{O}_{3}$ responses are then calculated in each grid cell, following West et al. [2007, 2009b], by scaling the change in $\mathrm{O}_{3}$ from the $\mathrm{CH}_{4}$ control simulation (SR2 minus SR1) to the calculated global $\mathrm{CH}_{4}$ change for

Table 3. Multimodel Mean \pm 1 Standard Deviation Reductions in the Anthropogenic Emissions of $\mathrm{NO}_{\mathrm{x}}, \mathrm{NMVOC}$, and $\mathrm{CO}(20 \%$ of Total Anthropogenic Emissions) Among the 11 HTAP CTMs Used Here $^{\mathrm{a}}$

\begin{tabular}{lccc}
\hline Region & $\mathrm{NO}_{\mathrm{x}}\left(\mathrm{Tg} \mathrm{N} \mathrm{a}^{-1}\right)$ & NMVOC $\left(\mathrm{Tg} \mathrm{C} \mathrm{a}^{-1}\right)$ & $\mathrm{CO}\left(\mathrm{Tg} \mathrm{a}^{-1}\right)$ \\
\hline EA & $1.17 \pm 0.24(0.20)$ & $3.13 \pm 1.24(0.40)$ & $25.58 \pm 7.25(0.28)$ \\
EU & $1.48 \pm 0.14(0.09)$ & $3.77 \pm 1.88(0.50)$ & $15.40 \pm 3.26(0.21)$ \\
$\mathrm{NA}$ & $1.48 \pm 0.10(0.07)$ & $3.11 \pm 1.34(0.43)$ & $19.69 \pm 3.66(0.19)$ \\
$\mathrm{SA}$ & $0.46 \pm 0.04(0.09)$ & $1.94 \pm 0.63(0.33)$ & $15.82 \pm 3.74(0.24)$ \\
\hline
\end{tabular}

${ }^{\mathrm{a}}$ Coefficient of variation $(\mathrm{CV}=$ standard deviation $/$ mean $)$ is in parentheses. Emissions for the individual CTMs are provided in Tables A2 and A3 of Fiore et al. [2009]. 


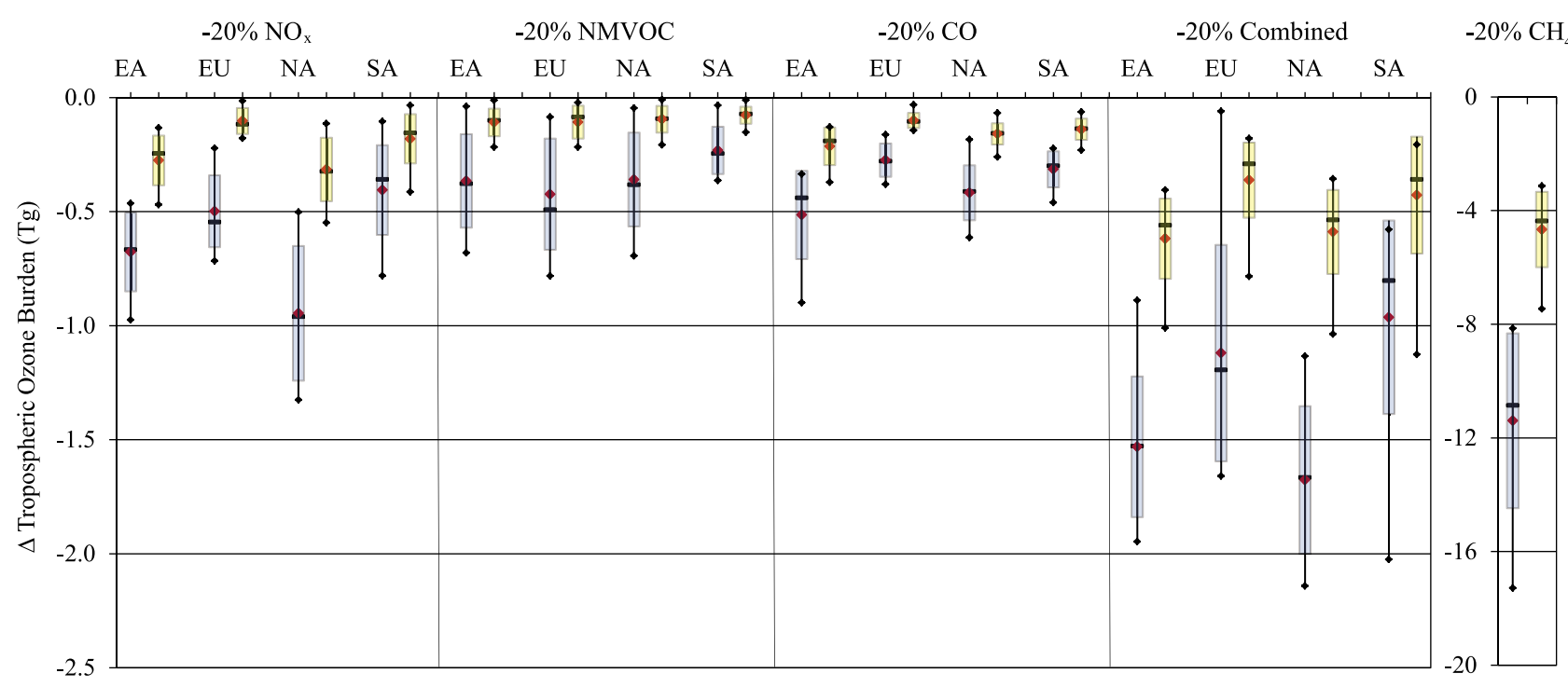

Figure 1. Global annual average changes in full (blue) and upper (yellow) tropospheric $\mathrm{O}_{3}$ burden $(\mathrm{Tg})$ at steady state (perturbation minus base), where the upper troposphere is from $500 \mathrm{hPa}$ to the tropopause, for the HTAP ensemble of 11 models, showing the median (black bars), mean (red points), mean $\pm 1 \mathrm{SD}$ (boxes), and max and min (whiskers), for each precursor reduction scenario $\left(-20 \%\right.$ global $\mathrm{CH}_{4}$ burden, and $-20 \%$ regional emissions of $\mathrm{NO}_{\mathrm{x}}, \mathrm{NMVOC}, \mathrm{CO}$, and combined from East Asia [EA], Europe and Northern Africa [EU], North America [NA], and South Asia [SA]).

each SR simulation and CTM. We then add the long-term $\mathrm{O}_{3}$ responses to the simulated short-term $\mathrm{O}_{3}$ responses to give $\mathrm{O}_{3}$ concentrations at steady state.

[12] Since the HTAP CTMs were typically not designed to model stratospheric chemistry, we use the same threedimensional monthly mean $\mathrm{O}_{3}$ concentrations in the stratosphere and merge these with calculated steady state (short-term + long-term) tropospheric $\mathrm{O}_{3}$ concentrations for each simulation and CTM. Stratospheric $\mathrm{O}_{3}$ is taken for the year 2001 from the AC\&C/SPARC $\mathrm{O}_{3}$ database prepared for CMIP5 (Available: http://pcmdi-cmip.llnl.gov/cmip5/ forcing.html). Søvde et al. [2011] found that around $15 \%$ of the RF from $\mathrm{O}_{3}$ precursors is due to $\mathrm{O}_{3}$ changes in the lower stratosphere, using a single model with both standard and updated chemistry. Since we ignore lower stratospheric $\mathrm{O}_{3}$ changes, our RF estimates may underestimate the full effect of $\mathrm{O}_{3}$ precursors. After each CTM's $\mathrm{O}_{3}$ and $\mathrm{SO}_{4}^{2-}$ results are interpolated to a common resolution (longitude $\times$ latitude $\times$ level $)$ as required by the RTM $\left(72 \times 37 \times 33\right.$ for $\mathrm{O}_{3}$; $96 \times$ $80 \times 14$ for $\mathrm{SO}_{4}^{2-}$ ), the HTAP ensemble mean \pm 1 standard deviation $\mathrm{O}_{3}$ and $\mathrm{SO}_{4}^{2-}$ distributions are calculated in each grid cell and month in three dimensions, in addition to the ensemble mean \pm 1 standard deviation global $\mathrm{CH}_{4}$ abundances (derived from the $\mathrm{CH}_{4}$ loss by tropospheric $\mathrm{OH}$ diagnostics). Global $\mathrm{O}_{3}, \mathrm{CH}_{4}$, and $\mathrm{SO}_{4}^{2-}$ changes are calculated for each CTM as perturbation (SR2 to SR6) minus base (SR1) values.

\subsection{GFDL Radiative Transfer Model}

[13] We employ the GFDL RTM to estimate the net RF at steady state due to the changes in atmospheric gases $\mathrm{CO}_{3}$ and $\mathrm{CH}_{4}$ ) alone and due to combined changes in $\mathrm{O}_{3}, \mathrm{CH}_{4}$, and $\mathrm{SO}_{4}^{2-}$ aerosols. The GFDL RTM is a module of the GFDL coupled atmospheric-ocean model (AM2) and simulates solar and infrared radiative transfer [GFDL GAMDT, 2004;
Naik et al., 2005, 2007]. It has been used in studies of longlived greenhouse gases [Schwarzkopf and Ramaswamy, 1999] and short-lived forcing agents such as $\mathrm{O}_{3}$ and aerosols [Naik et al., 2005, 2007; West et al., 2007; Fiore et al., 2008; Saikawa et al., 2009]. Here the RTM is employed as for Naik et al. [2007] and Saikawa et al. [2009], at $144 \times$ $90 \times 24$ levels, except for the following changes. We update well-mixed greenhouse gas concentrations based on observations for the year 2001 included as part of the historical period (1750-2005) of the CMIP5 Representative Concentration Pathways (RCP) database [Meinshausen et al., 2011] (Available: http://www.iiasa.ac.at/web-apps/tnt/RcpDb/ dsd?Action $=$ htmlpage\&page $=$ download). We also update the solar data used by the RTM to the CMIP5 solar forcing data (Available: http://www.geo.fu-berlin.de/en/met/ag/ strat/forschung/SOLARIS/Input data/CMIP5 solar irradiance. $\mathrm{html})$. The RTM simulations ${ }^{-}$do not include the indirect effects of aerosols on clouds or the internal mixing of aerosols. RF contributions from changes in nitrate aerosols, changes in stratospheric $\mathrm{O}_{3}$ and water vapor, changes to the carbon cycle via $\mathrm{O}_{3}$ and nitrogen deposition, and changes to $\mathrm{CO}_{2}$ from $\mathrm{CH}_{4}, \mathrm{CO}$, and NMVOC oxidation are also omitted in the RTM simulations.

[14] The multimodel monthly mean \pm 1 standard deviation $\mathrm{O}_{3}, \mathrm{CH}_{4}$, and $\mathrm{SO}_{4}^{2-}$ concentrations are used as input in the RTM simulations, along with meteorological fields from GFDL's atmosphere model (AM2) and land model (LM2), sampled one day per month at midmonth for the year 2001 to represent monthly mean conditions [Naik et al., 2005]. Substantial variability in the $\mathrm{SO}_{4}^{2-}$ estimates across only four CTMs precluded evaluating the mean -1 standard deviation for $\mathrm{SO}_{4}^{2-}$ (e.g., several grid cells had standard deviations exceeding the mean). We simulate the monthly mean net radiation fluxes for the base and perturbed cases and calculate the net RF as the difference between the perturbed and 


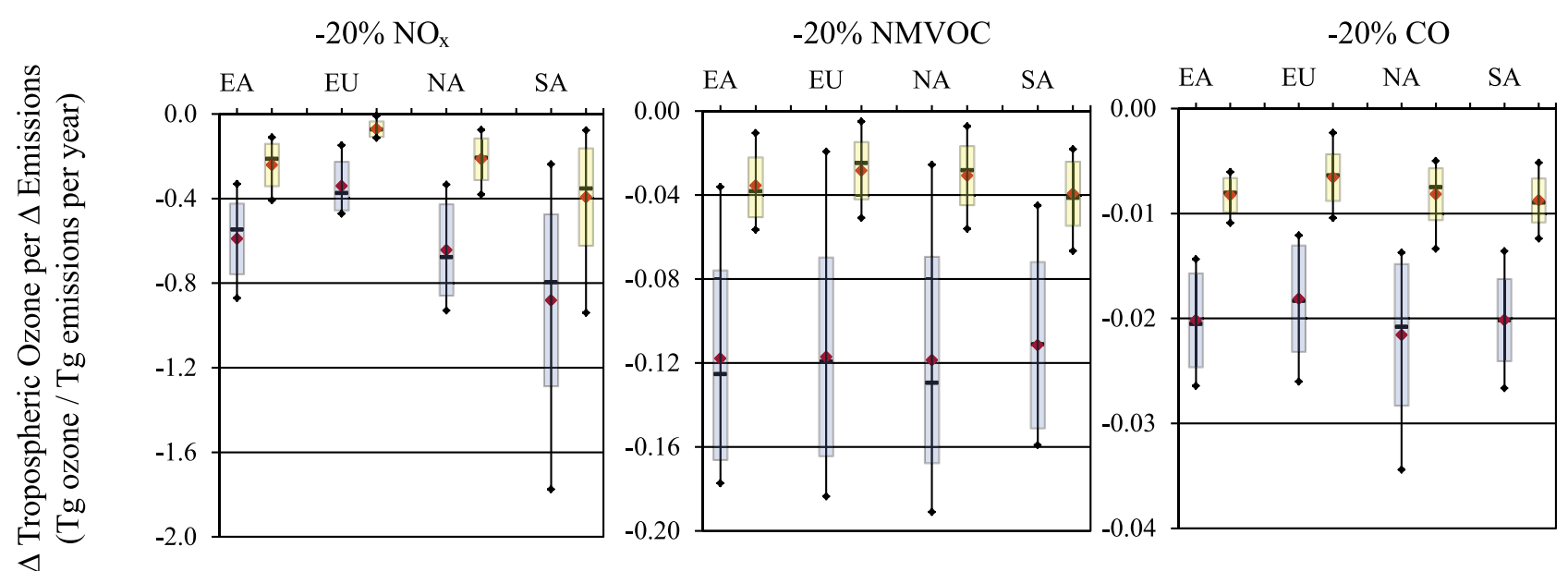

Figure 2. Global annual average changes in full (blue) and upper (yellow) tropospheric $\mathrm{O}_{3}$ burden per change in emissions ( $\mathrm{Tg} \mathrm{O}_{3} / \mathrm{Tg}$ emissions per year) at steady state for the individual 11 models, where the units of emissions are $\mathrm{Tg} \mathrm{N}$ (for $\mathrm{NO}_{\mathrm{x}}$ ), $\mathrm{Tg} \mathrm{C}$ (for NMVOCs), and $\mathrm{Tg} \mathrm{CO}$ (for $\mathrm{CO}$ ), showing the median (black bars), mean (red points), mean \pm 1 SD (boxes), and max and min (whiskers) across the HTAP ensemble.

base net fluxes (net shortwave minus net longwave) at the tropopause, after allowing stratospheric temperatures to readjust to radiative equilibrium [Naik et al., 2007; Saikawa et al., 2009].

\section{Tropospheric Composition Changes}

\subsection{Tropospheric Ozone Changes}

[15] Figure 1 shows the changes in global annually averaged steady state tropospheric $\mathrm{O}_{3}$ burden and its variability across 11 HTAP CTMs. Full troposphere and upper troposphere (UT) $\mathrm{O}_{3}$ burdens are distinguished because $\mathrm{O}_{3}$ in the UT has a higher RF efficiency on a per molecule basis [Lacis et al., 1990; Wang et al., 1993; Forster and Shine, 1997]. For each CTM's regridded $\mathrm{O}_{3}$ distributions that have been blended with CMIP5 stratospheric $\mathrm{O}_{3}$ values (section 2.1), the UT is defined from $500 \mathrm{hPa}$ to the tropopause, where the tropopause is identified at the 150 ppbv $\mathrm{O}_{3}$ level.

[16] The largest changes in full troposphere and UT $\mathrm{O}_{3}$ burden are found for the $20 \% \mathrm{CH}_{4}$ reduction, followed by the $20 \%$ combined precursor reductions from NA and EA, respectively. However, there is considerable diversity among the 11 CTMs' estimates of full troposphere and UT $\mathrm{O}_{3}$ burden changes. In these $17 \mathrm{SR}$ simulations relative to the base case, the change in $\mathrm{UT}_{3}$ burden per change in full troposphere $\mathrm{O}_{3}$ burden ( $\mathrm{UT} \mathrm{O}_{3} /$ full troposphere $\mathrm{O}_{3}$ ) is largest for reductions in global $\mathrm{CH}_{4}(0.36$ to 0.47$)$ and regional CO emissions (0.19 to 0.53$)$, and smallest for regional NMVOC reductions (0.16 to 0.42$)$ across the 11 CTMs, reflecting the longer lifetimes of $\mathrm{CO}$ and $\mathrm{CH}_{4}$ in comparison to NMVOCs and $\mathrm{NO}_{\mathrm{x}}$. UT $\mathrm{O}_{3} /$ full troposphere $\mathrm{O}_{3}$ is also largest for individual $\mathrm{O}_{3}$ precursor $\left(\mathrm{NO}_{\mathrm{x}}, \mathrm{NMVOC}\right.$, and $\left.\mathrm{CO}\right)$ reductions from $\mathrm{SA}$ in comparison to the other regions.

[17] To evaluate regional sensitivities, we consider how changes in full troposphere and UT $\mathrm{O}_{3}$ burdens per unit change in emissions vary by region for each precursor (Figure 2). The CTMs mostly agree that the SA $\mathrm{NO}_{\mathrm{x}}$ reduction produces the greatest change in full troposphere and UT $\mathrm{O}_{3}$ burden per change in emissions out of the four regions, which can be attributed to more rapid vertical mixing, stronger photochemistry, and greater sensitivity of $\mathrm{O}_{3}$ to precursor emissions from the tropics and southern hemisphere (SH) [Kunhikrishnan et al., 2004; West et al., 2009a]. We find less variability across the four regions in reducing full troposphere and $\mathrm{UT}_{3}$ burden per change in NMVOC and CO emissions (Figure 2), but six CTMs show that $\mathrm{SA}$ NMVOC and $\mathrm{CO}$ reductions produce the largest reductions in $\mathrm{UT} \mathrm{O}_{3}$ burden per change in emissions.

[18] For each regional reduction, the greatest changes in steady state tropospheric total column $\mathrm{O}_{3}$ occur over the reduction region, in each individual CTM and across the HTAP ensemble (Figure 3). For $\mathrm{NO}_{\mathrm{x}}$ reductions from each region, slight increases in $\mathrm{O}_{3}$ burden occur in the $\mathrm{SH}$, in contrast to overall decreases in the northern hemisphere $(\mathrm{NH})$, due to long-term $\mathrm{O}_{3}$ increases via $\mathrm{CH}_{4}$ that are globally distributed (according to the pattern of $\mathrm{O}_{3}$ response to $\mathrm{CH}_{4}$ ) [West et al., 2007, 2009b] (see section 3.2). As SA is further south than the other regions, the largest $\mathrm{O}_{3}$ decreases occur near the tropics and do not extend as far north. The slightly higher increases in $\mathrm{O}_{3}$ in the $\mathrm{SH}$ from the NA $\mathrm{NO}_{\mathrm{x}}$ reduction correspond to this region producing greater increases in global $\mathrm{CH}_{4}$ (Figure 4). For NMVOC and $\mathrm{CO}$ reductions from the four regions, we find decreases in total column $\mathrm{O}_{3}$ in both the $\mathrm{SH}$ and $\mathrm{NH}$, as sustained decreases in these precursors cause both short- and long-term global $\mathrm{O}_{3}$ decreases. NMVOC reductions also reduce global annual average peroxy acetyl nitrate (PAN) burdens from the four regions by $1.4 \pm 0.6 \%$ (SR4EA), $2.0 \pm 0.8 \%$ (SR4EU), $1.5 \pm 0.5 \%$ (SR4NA), and $0.5 \pm 0.2 \%$ (SR4SA), relative to the base, through which NMVOCs can influence the nitrogen cycle and therefore long-range $\mathrm{O}_{3}$. Across the 11 CTMs, we find that tropospheric PAN decreases are correlated to the changes in NMVOC emissions for the EA, EU, and NA reductions.

\subsection{Tropospheric Methane Changes}

[19] Although global $\mathrm{CH}_{4}$ was held constant by each CTM in all perturbations, we analyze the changes in global 
EA

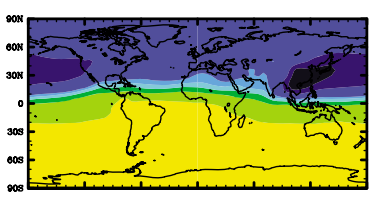

$-20 \%$ NMVOC

$-20 \% \mathrm{CO}$

$-20 \%$ Combined
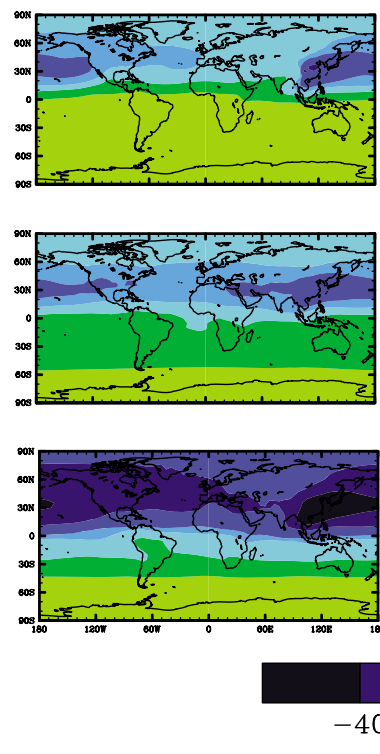

EU
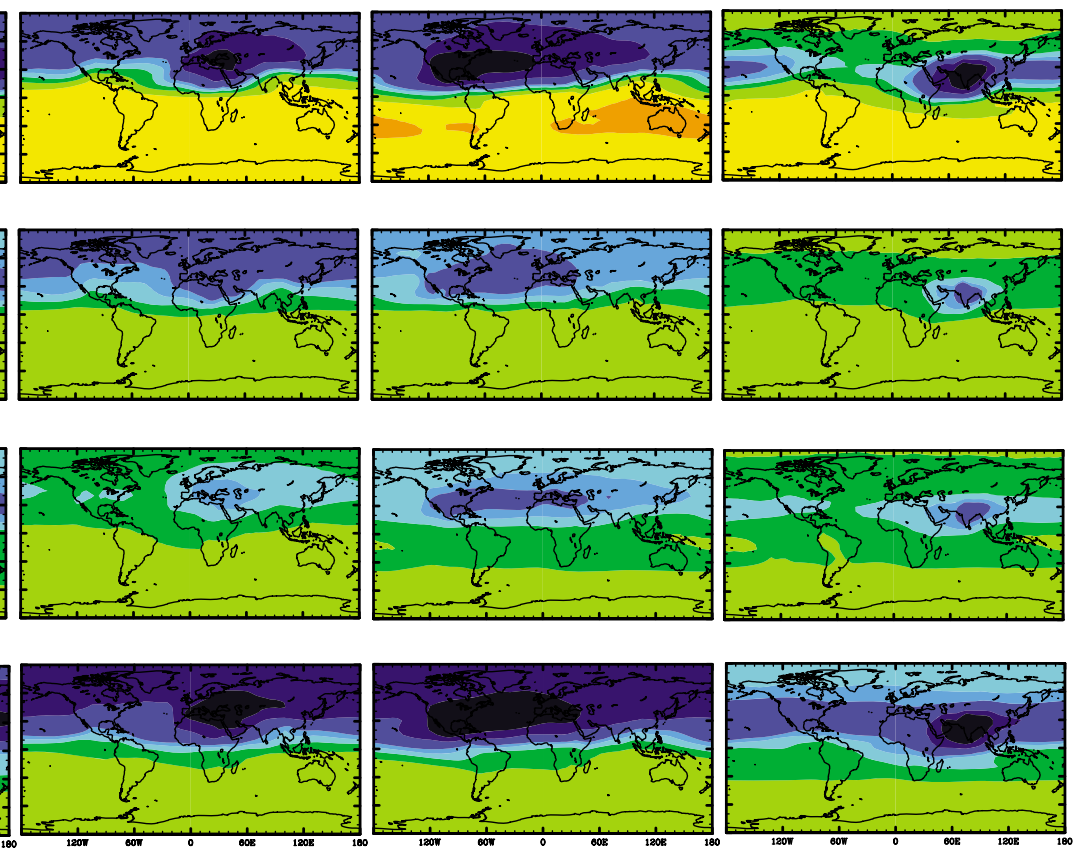

$10^{-2} \mathrm{DU}$

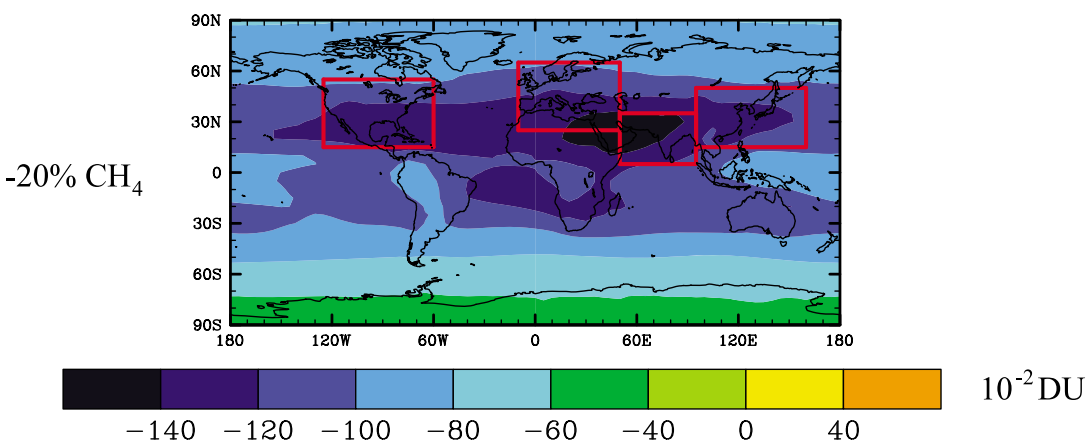

Figure 3. Annual average steady state tropospheric total column $\mathrm{O}_{3}$ burden changes $\left(10^{-2} \mathrm{DU}\right)$ for the multimodel mean of 11 HTAP models, for each of the precursor reduction scenarios $\left(-20 \% \mathrm{CH}_{4}\right.$ burden, and $-20 \%$ regional emissions of $\mathrm{NO}_{\mathrm{x}}, \mathrm{NMVOC}, \mathrm{CO}$, and combined). The 4 regions of reduction (NA, EU, SA, EA) are outlined in red in the $-20 \% \mathrm{CH}_{4}$ plot.

tropospheric $\mathrm{CH}_{4}$ calculated off-line for each perturbation. $\mathrm{NO}_{\mathrm{x}}$ reductions from all four regions increase global $\mathrm{CH}_{4}$ abundance via decreases in $\mathrm{OH}$, while NMVOC and $\mathrm{CO}$ reductions from all four regions decrease global $\mathrm{CH}_{4}$ (Figure 4). These changes in $\mathrm{CH}_{4}$ drive the long-term $\mathrm{O}_{3}$ changes discussed in the previous section. For particular precursors, reductions from certain regions, e.g., $\mathrm{CO}$ reductions from EA, are slightly more effective at decreasing global $\mathrm{CH}_{4}$ than other regions. However, there is noticeable variability among the CTMs' changes in global $\mathrm{CH}_{4}$ (Figure 4), which is partly explained by variance in CTM emissions for $\mathrm{CO}$, but not for $\mathrm{NO}_{\mathrm{x}}$ and NMVOCs.

[20] For several CTMs, some emissions perturbations had minimal impact on global $\mathrm{OH}$, resulting in calculated steady state $\mathrm{CH}_{4}$ changes of zero. In addition, the $\mathrm{CVs}$ of $\mathrm{CH}_{4}$ change are lowest in magnitude for $\mathrm{NO}_{\mathrm{x}}$ reductions $(0.22$ to
0.39 ) and highest for NMVOC reductions ( -0.40 to -1.12 ), perhaps reflecting differing NMVOC speciation and chemical schemes among the CTMs [Collins et al., 2002].

[21] We compare the change in global $\mathrm{CH}_{4}$ from the combined precursor reductions to the sum of global $\mathrm{CH}_{4}$ changes from $\mathrm{NO}_{\mathrm{x}}, \mathrm{NMVOC}$, and $\mathrm{CO}$ reductions to assess the additivity of individual precursor reductions on global $\mathrm{CH}_{4}$. Based on the HTAP multimodel mean results, global $\mathrm{CH}_{4}$ changes from SA and NA combined precursor reductions are approximately $59 \%$ and $75 \%$, respectively, of the sum of $\mathrm{CH}_{4}$ changes from individual precursor reductions, while global $\mathrm{CH}_{4}$ changes from EA and EU combined precursor reductions are slightly negative in contrast to small positive global $\mathrm{CH}_{4}$ changes from the sum. The three (of 11) CTMs that did not include reductions in $\mathrm{SO}_{2}$ and aerosols in the SR6 experiments [Fiore et al., 2009] show global $\mathrm{CH}_{4}$ 


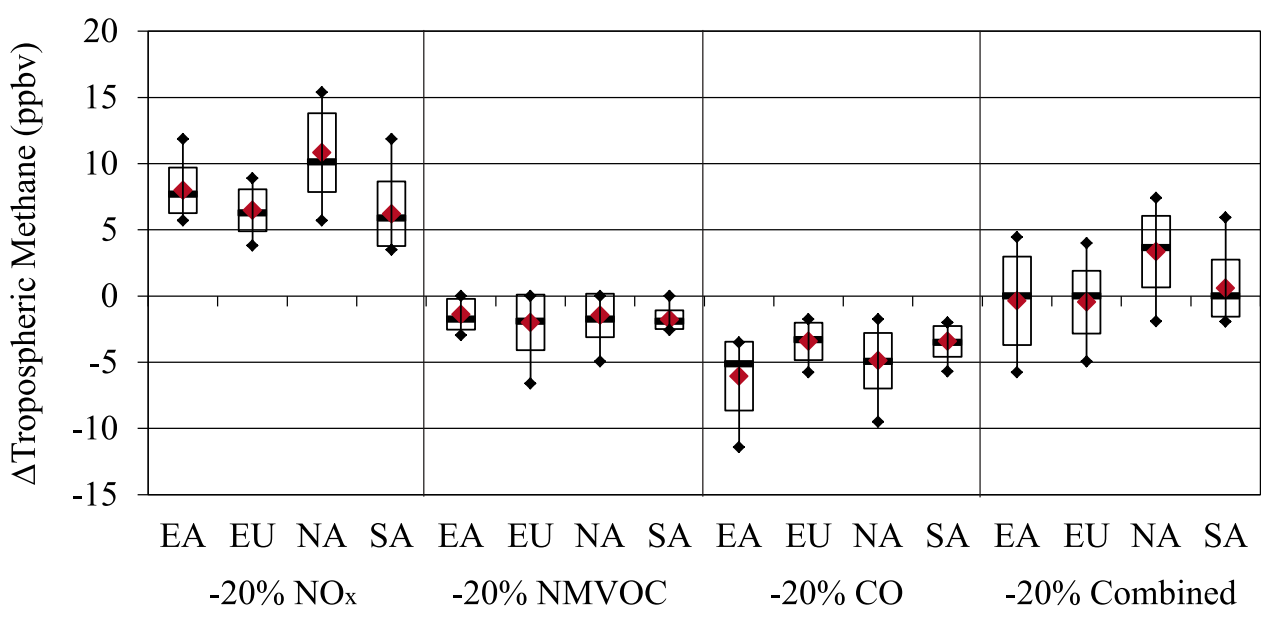

Figure 4. Global annual multimodel changes (perturbation minus 1760 ppbv) in tropospheric $\mathrm{CH}_{4}$ (ppbv) for $-20 \%$ regional emissions of $\mathrm{NO}_{\mathrm{x}}, \mathrm{NMVOC}, \mathrm{CO}$, and combined: median (black bars), mean (red points), mean $\pm 1 \mathrm{SD}$ (boxes), and max and min (whiskers) for the HTAP ensemble of 11 models, estimated directly from the $\mathrm{CH}_{4}$ loss by tropospheric $\mathrm{OH}$ archived by each HTAP CTM [Fiore et al., 2009]. Tropospheric $\mathrm{CH}_{4}$ changes were not available from INCA-vSSz for SA $20 \%$ NMVOC reduction and from LLNL-IMPACT-T5a for $20 \% \mathrm{NO}_{\mathrm{x}}$ reductions (EA, EU, NA, SA); these models are excluded from the multimodel $\mathrm{CH}_{4}$ changes for these perturbations.

changes from the combined precursor reductions close to the sum of $\mathrm{CH}_{4}$ changes from individual $\mathrm{NO}_{\mathrm{x}}, \mathrm{NMVOC}$, and $\mathrm{CO}$ reductions. This suggests that deviations from additivity may be due to reductions in $\mathrm{SO}_{2}$ and aerosols (in SR6) affecting $\mathrm{CH}_{4}$.

\subsection{Tropospheric Sulfate Changes}

[22] There is considerable variability and disagreement in the sign of $\mathrm{SO}_{4}^{2-}$ responses among the four CTMs evaluated (Figure 5). The greatest variability in global $\mathrm{SO}_{4}^{2-}$ burden across the CTMs occurs for the $\mathrm{CH}_{4}$ reduction and for $\mathrm{NO}_{\mathrm{x}}$ reductions from all four regions. There is less variability across CTMs for NMVOC and CO reductions, but still differences in the sign of change.
[23] The four CTMs analyzed here account for $\mathrm{SO}_{4}^{2-}$ formation through two main oxidation pathways: 1) gas-phase oxidation of sulfur dioxide $\left(\mathrm{SO}_{2}\right)$ by $\mathrm{OH}$, and 2) aqueousphase oxidation of $\mathrm{SO}_{2}$ by $\mathrm{H}_{2} \mathrm{O}_{2}$ or $\mathrm{O}_{3}$ [Houweling et al., 1998; Jeuken et al., 1999, 2001; Barth et al., 2000; Rasch et al., 2000; Horowitz et al., 2003; Rotman et al., 2004; Tie et al., 2005]. Since $\mathrm{CH}_{4}, \mathrm{NMVOC}$, and $\mathrm{CO}$ reductions increase $\mathrm{OH}$ concentrations, $\mathrm{SO}_{2}$ oxidation via pathway (1) is expected to increase tropospheric $\mathrm{SO}_{4}^{2-}$ formation. At the same time, increases in $\mathrm{H}_{2} \mathrm{O}_{2}$ (occurring with increases in $\mathrm{OH}$ ) are expected to increase $\mathrm{SO}_{2}$ oxidation via pathway (2), but decreases in $\mathrm{O}_{3}$ may decrease oxidation (also pathway (2)). $\mathrm{NO}_{\mathrm{x}}$ reductions not only decrease $\mathrm{O}_{3}$, but can also decrease $\mathrm{OH}$ and $\mathrm{H}_{2} \mathrm{O}_{2}$, which leads to decreases in

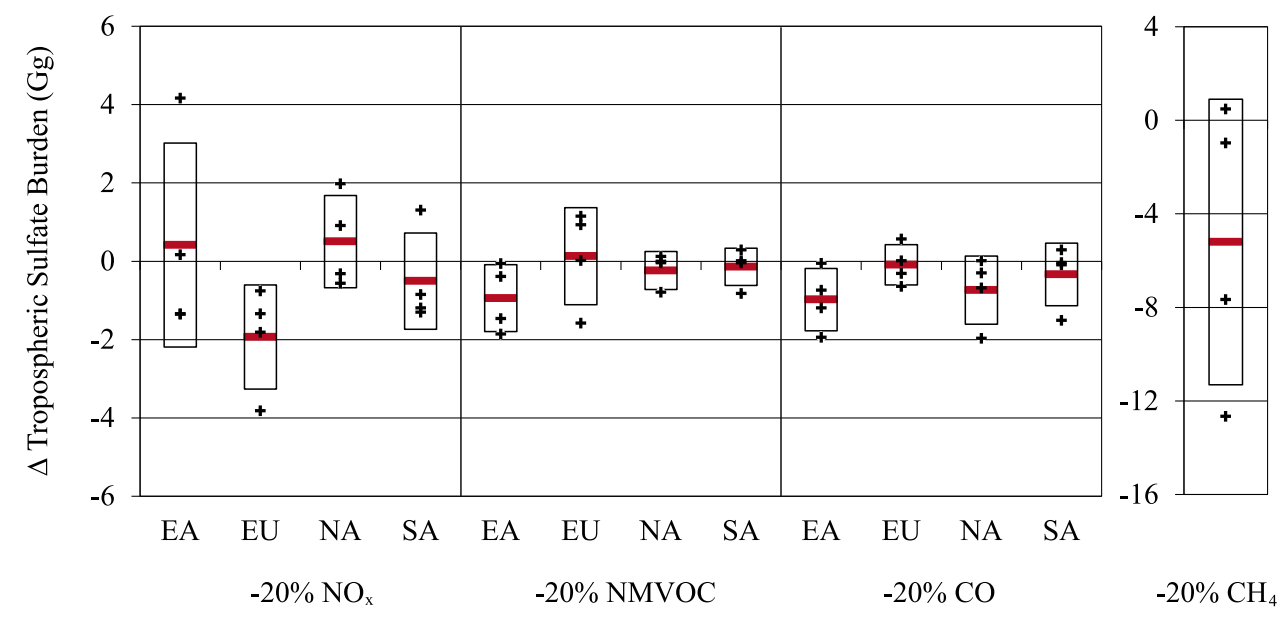

Figure 5. Global annual multimodel changes (perturbation minus base) in short-term tropospheric $\mathrm{SO}_{4}^{2-}$ (Gg) for $-20 \% \mathrm{CH}_{4}$ burden and $-20 \%$ regional emissions of $\mathrm{NO}_{\mathrm{x}}$, NMVOC, and $\mathrm{CO}$ : mean (red bars) and mean \pm 1 SD (boxes) across the HTAP ensemble of four models. The individual model results are shown in black (pluses). 


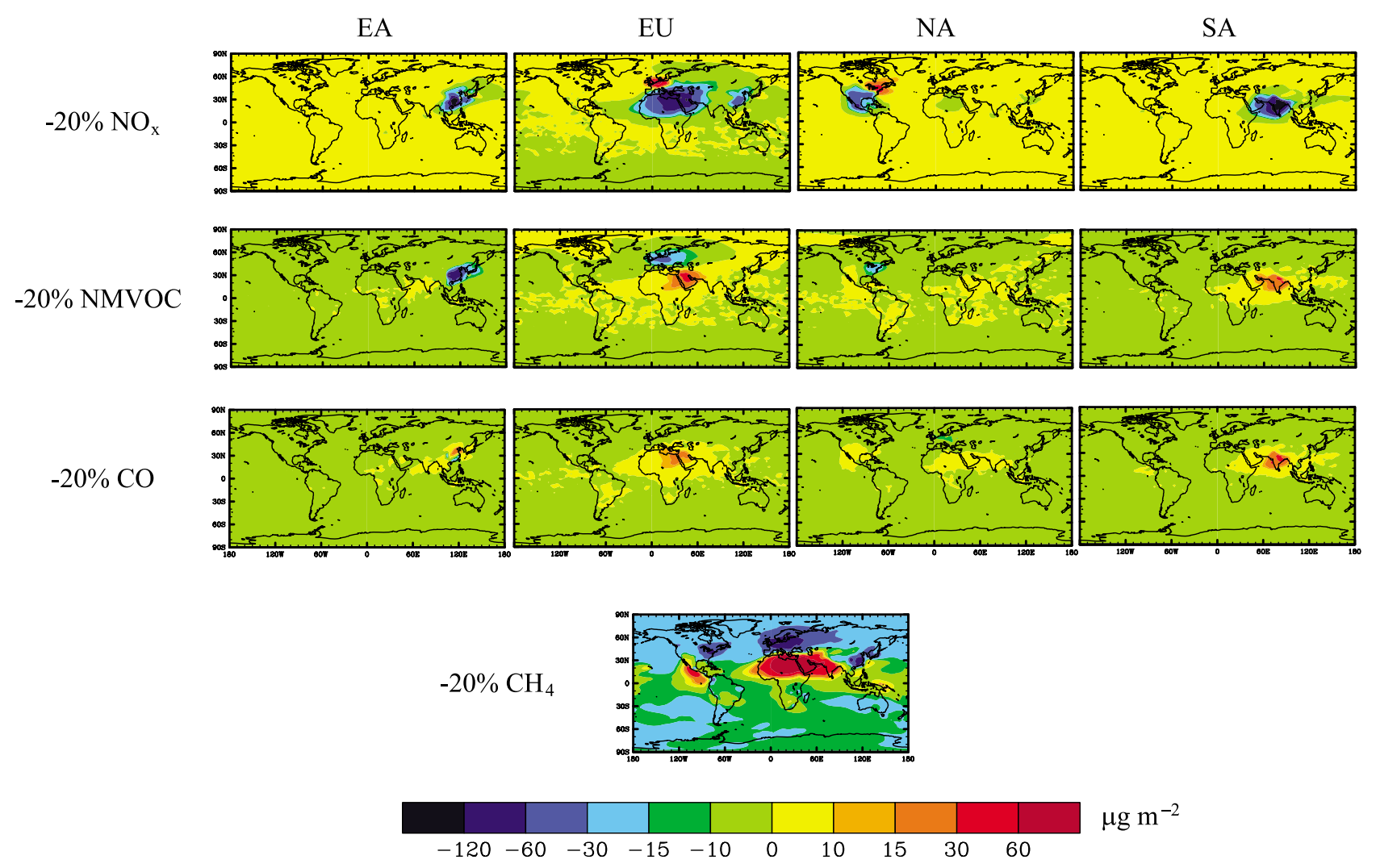

Figure 6. Annual average tropospheric total column $\mathrm{SO}_{4}^{2-}$ burden changes $\left(\mu \mathrm{g} \mathrm{m}^{-2}\right)$ for the multimodel mean of four HTAP models for $-20 \% \mathrm{CH}_{4}$ burden and $-20 \%$ regional emissions of $\mathrm{NO}_{\mathrm{x}}, \mathrm{NMVOC}$, and $\mathrm{CO}$ scenarios.

$\mathrm{SO}_{4}^{2-}$ formation by pathways (1) and (2). Figure 5 shows that the sign of $\mathrm{SO}_{4}^{2-}$ response is not consistent across all four CTMs, suggesting uncertainty in the modeled effects of $\mathrm{O}_{3}$ precursors on oxidants, the relative importance of these oxidation pathways, and the lifetime and removal of $\mathrm{SO}_{2}$ and $\mathrm{SO}_{4}^{2-}$.

[24] The global distributions of tropospheric total column $\mathrm{SO}_{4}^{2-}$ changes (Figure 6) show the greatest changes in $\mathrm{SO}_{4}^{2-}$ over the region of emission change, with only slight changes globally. The individual CTMs and HTAP ensemble mean results show that $\mathrm{NO}_{\mathrm{x}}$ reductions from $\mathrm{EA}, \mathrm{EU}$, and $\mathrm{NA}$ cause both increases and decreases in $\mathrm{SO}_{4}^{2-}$ over the reduction region, which correspond to changes in oxidants $(\mathrm{OH}$, $\left.\mathrm{H}_{2} \mathrm{O}_{2}, \mathrm{O}_{3}\right)$; localized decreases in $\mathrm{SO}_{4}^{2-}$ are due in part, to localized decreases in $\mathrm{OH}$ (auxiliary material Figure S5) and decreases in $\mathrm{O}_{3}{ }^{1}{ }^{1}$ The distributions of $\mathrm{H}_{2} \mathrm{O}_{2}$ are not analyzed, as they were not reported in the $\mathrm{CTM}$ simulations. NMVOC reductions from EU increase $\mathrm{SO}_{4}^{2-}$ over northeastern Africa and decrease $\mathrm{SO}_{4}^{2-}$ over western Europe in three of the CTMs and the ensemble mean. All four CTMs consistently show that the EA NMVOC reduction decreases $\mathrm{SO}_{4}^{2-}$ and the SA NMVOC reduction increases $\mathrm{SO}_{4}^{2-}$ regionally, while two CTMs show $\mathrm{SO}_{4}^{2-}$ decreases over the eastern U.S. from the NA NMVOC reduction. For CO reductions from all four regions, the ensemble mean shows localized increases, while the individual CTMs differ in the

\footnotetext{
${ }^{1}$ Auxiliary materials are available in the HTML. doi:10.1029/ 2011JD017134.
}

sign of regional $\mathrm{SO}_{4}^{2-}$ change for all $\mathrm{CO}$ reductions except SA. Regional increases in $\mathrm{SO}_{4}^{2-}$ from the NMVOC and $\mathrm{CO}$ reductions can be explained partly by localized increases in $\mathrm{OH}$ (Figure S5); however, decreases in $\mathrm{SO}_{4}^{2-}$ may be related to the differing effects on oxidants (including $\mathrm{H}_{2} \mathrm{O}_{2}$ ) and on the $\mathrm{SO}_{2}$ oxidation pathways in each CTM, as discussed in the previous paragraph.

\section{Radiative Forcing due to Precursor Emission Changes}

[25] Figure 7 (and Table $\mathrm{S} 1$ in auxiliary material Text $\mathrm{S} 1$ ) show the global annual net $\mathrm{RF}$ due to $\mathrm{O}_{3}, \mathrm{CH}_{4}$, and $\mathrm{SO}_{4}^{2-}$, estimated from RTM simulations, first for multimodel mean $\mathrm{O}_{3}$ and $\mathrm{CH}_{4}$, and second for multimodel mean $\mathrm{O}_{3}, \mathrm{CH}_{4}$, and $\mathrm{SO}_{4}^{2-}$, for each SR scenario relative to the base case. We calculated the net RF distributions for each perturbation scenario (SR2 through SR6) by subtracting (in each grid cell and month) the simulated radiative fluxes for the base case (SR1) from those for each perturbation. To estimate the contribution of the multimodel mean $\mathrm{SO}_{4}^{2-}$ to the global annual net RF, we subtracted the net RF results due to $\mathrm{O}_{3}$ and $\mathrm{CH}_{4}$ from the net $\mathrm{RF}$ due to $\mathrm{O}_{3}, \mathrm{CH}_{4}$, and $\mathrm{SO}_{4}^{2-}$ for each SR scenario, assuming the effects of $\mathrm{O}_{3}, \mathrm{CH}_{4}$, and $\mathrm{SO}_{4}^{2-}$ are additive. To distinguish the contributions of $\mathrm{O}_{3}$ and $\mathrm{CH}_{4}$ to the global annual net RF, we estimated the net RF due to the multimodel mean $\mathrm{CH}_{4}$ for each SR scenario, using the formula of Ramaswamy et al. [2001], attributing the difference to $\mathrm{O}_{3} \mathrm{RF}$. 
a)

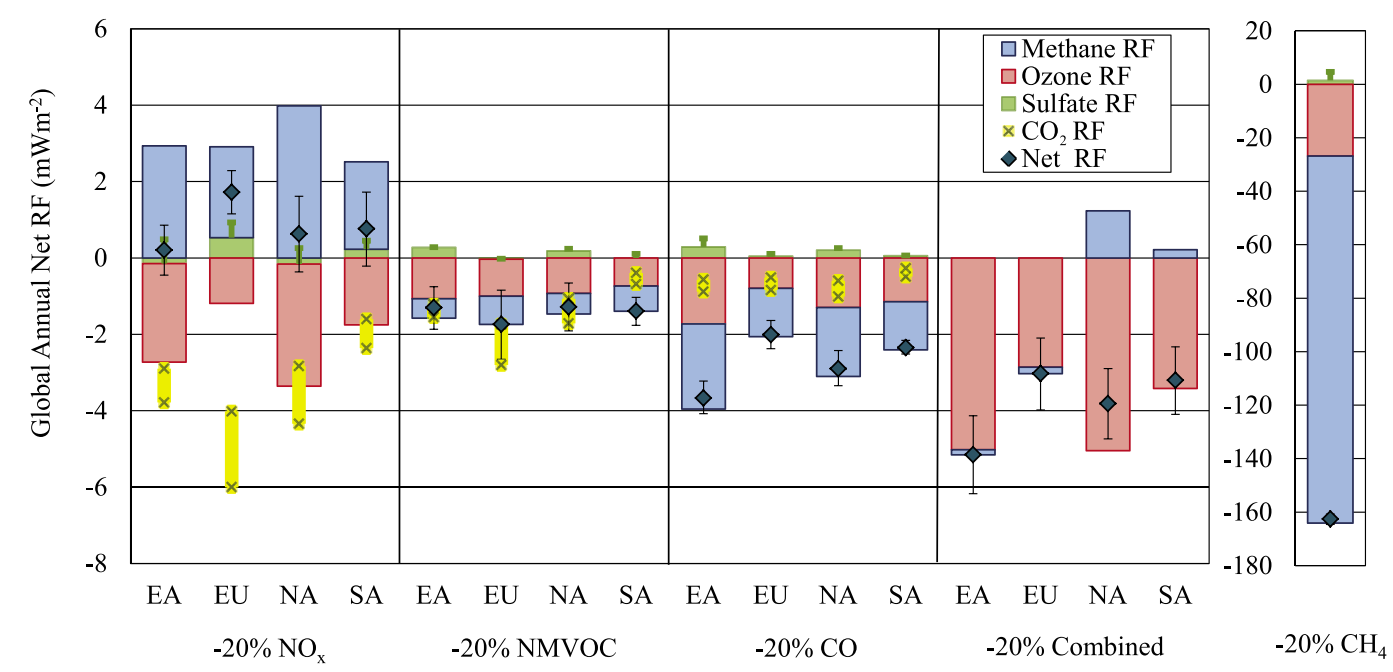

b)
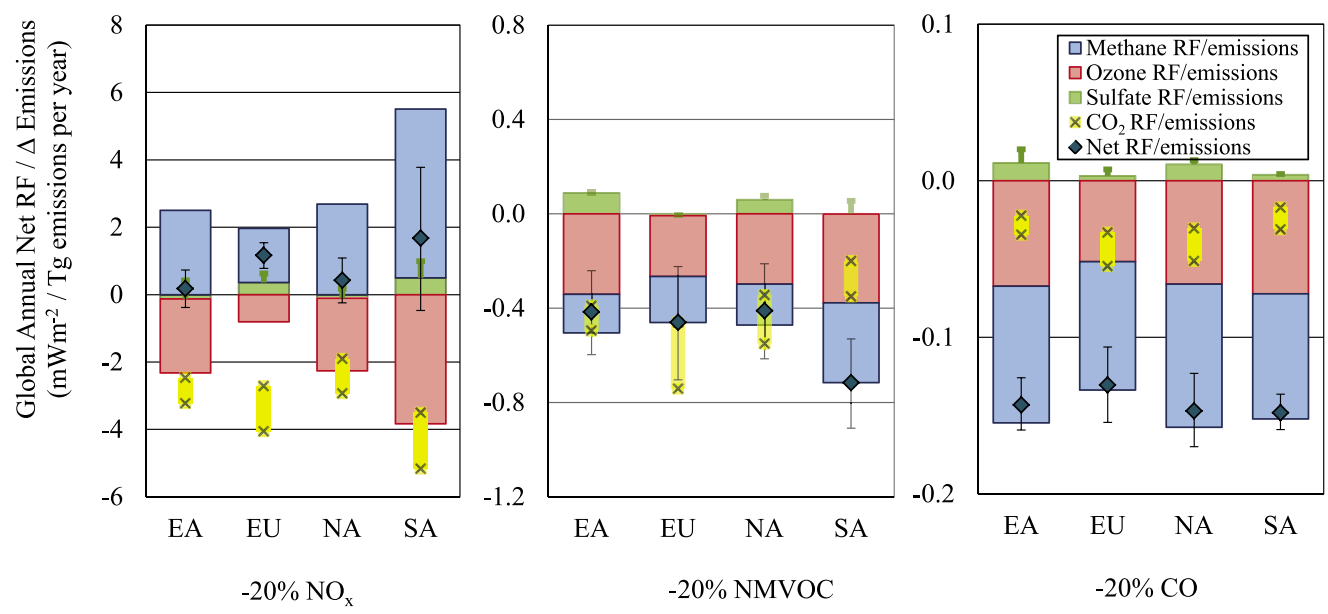

Figure 7. (a) Global annual average $\mathrm{RF}\left(\mathrm{mW} \mathrm{m}^{-2}\right.$ ) for the HTAP ensembles of 11 models (for $\mathrm{O}_{3}$ and $\mathrm{CH}_{4}$ forcing) and four models (for $\mathrm{SO}_{4}^{2-}$ forcing) due to multimodel mean changes in steady state $\mathrm{O}_{3}$, $\mathrm{CH}_{4}$, and $\mathrm{SO}_{4}^{2-}$. Vertical black bars represent the uncertainty in net $\mathrm{RF}$ across models, calculated as the net $\mathrm{RF}$ of the multimodel mean \pm 1 standard deviation $\mathrm{O}_{3}$ and $\mathrm{CH}_{4}$, for each perturbation $\left(-20 \% \mathrm{CH}_{4}\right.$ burden, and $-20 \%$ regional emissions of $\mathrm{NO}_{\mathrm{x}}, \mathrm{NMVOC}, \mathrm{CO}$, and combined), relative to the base simulation. The uncertainty estimates for $-20 \% \mathrm{CH}_{4}$ account only for the variability in simulated $\mathrm{O}_{3}$ changes across the CTMs, since all CTMs uniformly reduced $\mathrm{CH}_{4}(1760 \mathrm{ppbv}$ to $1408 \mathrm{ppbv})$. Vertical green bars represent the upper uncertainty bound of $\mathrm{SO}_{4}^{2-} \mathrm{RF}$ across models, calculated as the net $\mathrm{RF}$ of the multimodel mean +1 standard deviation $\mathrm{SO}_{4}^{2-}$. The $\mathrm{RF}$ of changes in $\mathrm{CO}_{2}$ uptake by the biosphere (yellow) are shown as a range from high to low sensitivity of vegetation to $\mathrm{O}_{3}$, estimated for a single CTM (STOCHEM) by Collins et al. [2010]; these estimates are not included in the net RF (supporting data provided in Table S1 in auxiliary material Text S1). Note the difference in scale between the $-20 \%$ regional $\left(\mathrm{NO}_{\mathrm{x}}, \mathrm{NMVOC}, \mathrm{CO}\right.$, combined) and $-20 \% \mathrm{CH}_{4}$ reduction scenarios. (b) Global, annual average RF per multimodel mean change in emissions $\left(\mathrm{mW} \mathrm{m}^{-2} / \mathrm{Tg}\right.$ emissions per year) due to multimodel mean changes in steady state $\mathrm{O}_{3}, \mathrm{CH}_{4}$, and $\mathrm{SO}_{4}^{2-}$, and uncertainty (vertical black bars) as the net $\mathrm{RF}$ of the multimodel mean \pm 1 standard deviation changes in $\mathrm{O}_{3}$ and $\mathrm{CH}_{4}$ per unit change in emissions for each perturbation, relative to the base simulation. Vertical green bars represent the upper uncertainty bound of $\mathrm{SO}_{4}^{2-} \mathrm{RF}$ per unit change in emissions across models. 


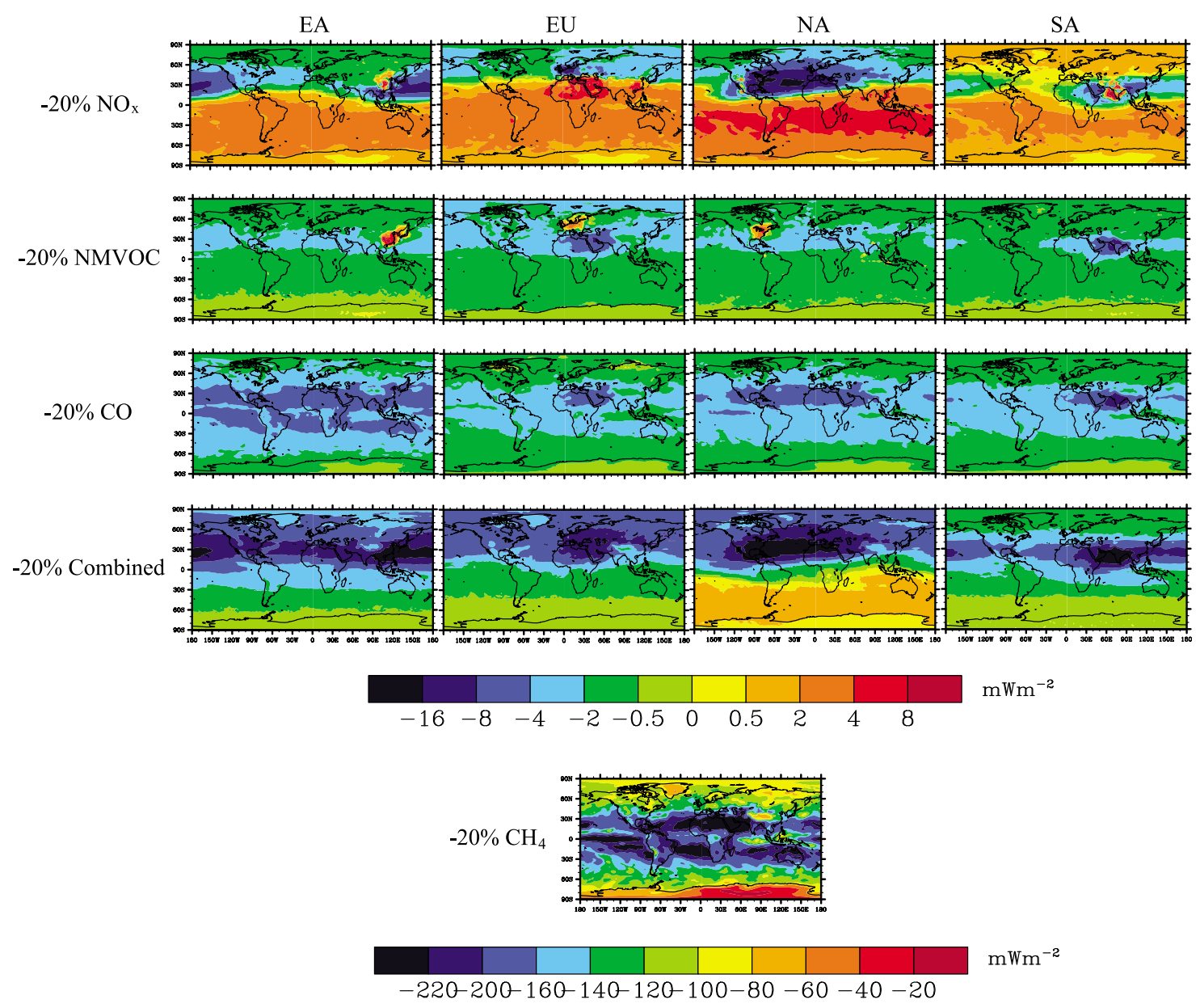

Figure 8. Annual average net $\mathrm{RF}$ distributions $\left(\mathrm{mW} \mathrm{m}^{-2}\right)$, calculated as the annual shortwave radiation minus the annual longwave radiation, due to tropospheric $\mathrm{O}_{3}, \mathrm{CH}_{4}$, and $\mathrm{SO}_{4}^{2-}$ for the multimodel mean, for each of the precursor reduction simulations $\left(-20 \% \mathrm{CH}_{4}\right.$ burden and $-20 \%$ regional emissions of $\mathrm{NO}_{\mathrm{x}}, \mathrm{NMVOC}, \mathrm{CO}$, and combined) minus the base simulation. Note the difference in scale between the $-20 \%$ regional $\left(\mathrm{NO}_{\mathrm{x}}, \mathrm{NMVOC}, \mathrm{CO}\right.$, combined) and $-20 \% \mathrm{CH}_{4}$ reduction scenarios.

[26] Computational limitations prevented us from simulating the RFs individually for each CTM's 18 SR scenarios. Instead, we simulate RFs for multimodel means, and for the multimodel mean \pm 1 standard deviation $\mathrm{O}_{3}$ and $\mathrm{CH}_{4}$ and the multimodel mean +1 standard deviation $\mathrm{SO}_{4}^{2-}$ to account for uncertainty in the net RF due to differences in the CTMs. We show uncertainty (mean \pm 1 standard deviation) for the resulting net RF, which includes the uncertainty in $\mathrm{O}_{3}$ and $\mathrm{CH}_{4} \mathrm{RFs}$, as changes in $\mathrm{O}_{3}$ and $\mathrm{CH}_{4}$ are not strongly correlated among the 11 CTMs for most scenarios (Figure S4). For $\mathrm{NO}_{\mathrm{x}}$ reductions, because the $\mathrm{RF}$ due to $\mathrm{O}_{3}$ opposes that of $\mathrm{CH}_{4}$, a broader uncertainty range would have resulted had we instead simulated together the multimodel mean +1 standard deviation $\mathrm{O}_{3}$ and the multimodel mean -1 standard deviation $\mathrm{CH}_{4}$ (and the reverse) to estimate uncertainty.

[27] Figure 7 shows that $\mathrm{O}_{3}$ and $\mathrm{CH}_{4} \mathrm{RFs}$ have the same sign as the tropospheric composition changes in section 3; since $\mathrm{SO}_{4}^{2-}$ is cooling, $\mathrm{SO}_{4}^{2-} \mathrm{RF}$ has the opposite sign. $\mathrm{NO}_{\mathrm{x}}$ reductions from all four regions produce an overall positive net $\mathrm{RF}$ due to increases in $\mathrm{CH}_{4}$, which outweigh the negative net $\mathrm{RF}$ due to decreases in $\mathrm{O}_{3}$ (Figure 7a). Negative global net RFs are produced by $\mathrm{CO}$ and NMVOC reductions, due to $\mathrm{O}_{3}$ and $\mathrm{CH}_{4}$ decreases, and also by the combined precursor reductions, as increases in $\mathrm{CH}_{4}$ from $\mathrm{NO}_{\mathrm{x}}$ reductions roughly cancel $\mathrm{CH}_{4}$ decreases from NMVOC and CO reductions [Fiore et al., 2009]. The net $\mathrm{RF}$ due to the combined precursor reduction is $98 \%$ to $117 \%$ of the sum of the net RFs (of $\mathrm{O}_{3}$ and $\mathrm{CH}_{4}$ ) due to reductions of each individual precursor, across the four regions, showing approximate additivity for the different precursors.

[28] Consistent with the $\mathrm{SO}_{4}^{2-}$ changes in Figure $5, \mathrm{NO}_{x}$ reductions from $\mathrm{EU}$ and $\mathrm{SA}$ contribute a positive $\mathrm{SO}_{4}^{2-} \mathrm{RF}$, while EA and $\mathrm{NA} \mathrm{NO}_{\mathrm{x}}$ reductions produce negative $\mathrm{SO}_{4}^{2-}$ $\mathrm{RF}$. The $\mathrm{SO}_{4}^{2-} \mathrm{RFs}$ for NMVOC and $\mathrm{CO}$ reductions vary in magnitude and sign across the four regions, corresponding to the disagreement in $\mathrm{SO}_{4}^{2-}$ response across the CTMs (Figure 5). We do not estimate the contribution of $\mathrm{SO}_{4}^{2-}$ to net RF for the combined reductions, since many of these perturbations included $20 \%$ reductions in $\mathrm{SO}_{2}$ and aerosols, making it difficult to isolate the effect of $\mathrm{NO}_{\mathrm{x}}, \mathrm{NMVOC}$, and $\mathrm{CO}$ on $\mathrm{SO}_{4}^{2-} \mathrm{RF}$.

[29] Figure 7 also shows an estimate of the RF due to the $\mathrm{CO}_{2}$ equivalent emission resulting from the influence of surface $\mathrm{O}_{3}$ on plants' ability to remove $\mathrm{CO}_{2}$ from the 


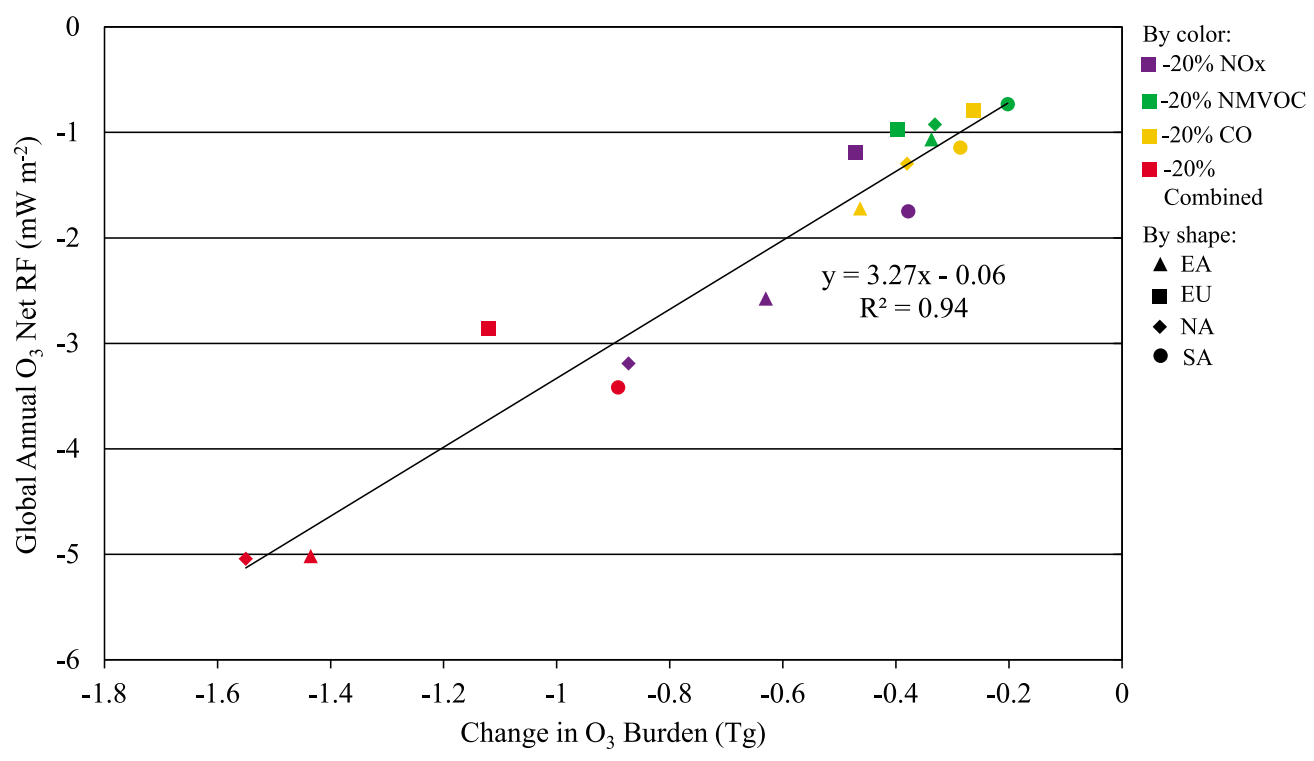

Figure 9. Radiative forcing efficiency of $\mathrm{O}_{3}$ for the $16 \mathrm{SR}$ simulations (SR3 through SR6) for the multimodel mean, showing the global, annual average $\mathrm{O}_{3}$ net $\mathrm{RF}\left(\mathrm{mW} \mathrm{m}^{-2}\right)$, calculated as the difference between the simulated net RF due to $\mathrm{O}_{3}$ and $\mathrm{CH}_{4}$ and estimated net RF due to $\mathrm{CH}_{4}$ [Ramaswamy et al., 2001], versus the global, annual average steady state changes in tropospheric $\mathrm{O}_{3}$ burden (Tg). The SR simulations are distinguished by precursor (color) and region (shape).

atmosphere, from Collins et al. [2010], based on one HTAP CTM (STOCHEM) and not the HTAP ensemble. The $\mathrm{CO}_{2}$ responses to pulse changes from Collins et al. [2010] were converted to equilibrium responses by integrating over 100 years. The range of $\mathrm{CO}_{2} \mathrm{RF}$ represents high to low sensitivity of vegetation to $\mathrm{O}_{3}$. With the additional consideration of $\mathrm{CO}_{2} \mathrm{RF}$, the global annual net $\mathrm{RF}$ due to regional $\mathrm{NO}_{\mathrm{x}}$ reductions changes sign to an overall net climate cooling ( -0.83 to $-4.28 \mathrm{mWm}^{-2}$ for all four regions), while the negative net RFs for regional NMVOC and $\mathrm{CO}$ reductions are reinforced by the addition of $\mathrm{CO}_{2} \mathrm{RF}$ (Table $\mathrm{S} 1$ in auxiliary material Text $\mathrm{S} 1$ ).

[30] We normalize the global annual net RF estimates (Figure 7a) by each region's reduction in emissions (Table 3). The net RF per unit change in $\mathrm{NO}_{\mathrm{x}}$ and NMVOC emissions is greatest for SA reductions out of the four regions (Figure $7 \mathrm{~b}$ ), corresponding to the sensitivity findings in section 3.1. For CO reductions, all four regions are approximately as effective at reducing global net RF per unit $\mathrm{CO}$ emissions, consistent with CO's longer atmospheric lifetime.

[31] We compare our ensemble mean global annual net RF estimates per unit $\mathrm{NO}_{\mathrm{x}}$ emissions to those of Naik et al. [2005], who used a single CTM and analyzed $10 \% \mathrm{NO}_{\mathrm{x}}$ reductions. Our estimates are approximately $32 \%$ to $63 \%$ (EU, NA, SA) and 16\% (EA) of those reported by Naik et al. [2005], but these differences in net $\mathrm{RF}\left(\mathrm{CH}_{4}\right.$ and $\mathrm{O}_{3} \mathrm{RF}$ combined) are small in comparison to the magnitudes of $\mathrm{CH}_{4}$ and $\mathrm{O}_{3}$ forcing individually.

[32] The net RF distributions (Figure 8) correspond to the distributions of total column $\mathrm{O}_{3}$ (Figure 3) and $\mathrm{SO}_{4}^{2-}$ changes (Figure 6), where regional to hemispheric RF corresponds to $\mathrm{O}_{3}$ changes and more localized $\mathrm{RF}$ is dominated by $\mathrm{SO}_{4}^{2-}$ changes, as illustrated by shortwave forcings (Figure S2). Changes in $\mathrm{CH}_{4}$ influence net RF globally, since a uniform $\mathrm{CH}_{4}$ mixing ratio was specified in each RTM simulation. For $\mathrm{NO}_{\mathrm{x}}$ reductions, we find positive net RFs in the SH due to $\mathrm{CH}_{4}$ and long-term $\mathrm{O}_{3}$ increases globally, but in the NH these positive RFs are outweighed by the negative $\mathrm{RF}$ of $\mathrm{O}_{3}$ decreases (Figure 8). For $\mathrm{CH}_{4}$, NMVOC, $\mathrm{CO}$, and combined reductions, negative net RFs from $\mathrm{O}_{3}$ decreases in the $\mathrm{NH}$ overlay negative RFs globally due to $\mathrm{CH}_{4}$. While Figure 7 presents globally averaged forcings, the regionally inhomogeneous forcings in Figure 8 are also relevant for regional climate change [Shindell and Faluvegi, 2009]. However, regional RF patterns resulting from changes in tropospheric loadings do not directly translate to regional climate responses [Levy et al., 2008; Shindell et al., 2010].

[33] In Figure 9, the relationship between tropospheric $\mathrm{O}_{3}$ burden changes and global $\mathrm{O}_{3} \mathrm{RF}$ is strongly linear, giving a RF efficiency of approximately $3.27 \mathrm{~mW} \mathrm{~m}^{-2}$ per $\mathrm{Tg} \mathrm{O}$ or $35.6 \mathrm{mWm}^{-2} \mathrm{DU}^{-1}$ ( $1 \mathrm{DU} \approx 10.88 \mathrm{Tg} \mathrm{O}_{3}$ [Park et al., 1999]). This efficiency compares well with those estimated in previous studies, 34 to $48 \mathrm{mWm}^{-2} \mathrm{DU}^{-1}$ [Hauglustaine and Brasseur, 2001; Wild et al., 2001; Fiore et al., 2002] and $23 \mathrm{mWm}^{-2} \mathrm{DU}^{-1}$ (for $\mathrm{NO}_{\mathrm{x}}$ ) and $43 \mathrm{mWm}^{-2} \mathrm{DU}^{-1}$ (for $\mathrm{CH}_{4}$ and $\mathrm{CO}+\mathrm{VOCs}$ ) [Shindell et al., 2005]. Here reductions from EU and NA (with exception of NA $\mathrm{NO}_{\mathrm{x}}$ ) fall at or above the average RF efficiency line, suggesting lower RF efficiency. EA and SA reductions (except for EA NMVOC) have RF efficiency greater than average, as these regions have greater influences on the UT where RF is the most efficient [Lacis et al., 1990; Wang et al., 1993; Forster and Shine, 1997; West et al., 2009a].

\section{Global Warming Potentials}

[34] Beyond analyzing RF, the climate impacts of $\mathrm{O}_{3}$ precursor emissions can be compared with each other, and 
with the emissions of other species using climate metrics such as the global warming potential (GWP). Forster et al. [2007] suggest that there are serious limitations to the use of GWPs for comparing short-lived species. While other metrics have been proposed to compare climate effects, such as the global temperature potential (GTP) [Shine et al., 2005, 2007], none are as widely used as the GWP. We choose to analyze the GWP here for comparison with earlier studies.

[35] The basis for the GWP calculation is the integrated $\mathrm{RF}$ following a pulse emission. In section $4, \mathrm{O}_{3} \mathrm{RF}$ was calculated for equilibrium conditions for the sum of the short and long-term $\mathrm{O}_{3}$ responses (Figure 7, and Table $\mathrm{S} 1$ in auxiliary material Text S1). Here long-term $\mathrm{O}_{3} \mathrm{RF}$ is calculated by scaling $\mathrm{O}_{3}$ RF from SR2 by the ratio of steady state $\mathrm{O}_{3}$ burden change in a particular SR scenario (SR minus base) to those of SR2 (SR2 minus base). The short-term $\mathrm{O}_{3} \mathrm{RF}$ is then the difference between the steady state RF (section 4) and long-term RF. Following Collins et al. [2010], RF as a function of time is calculated for a one-year emissions perturbation, for each SR scenario. The short-term RF components $\left(\mathrm{SO}_{4}^{2-}\right.$ and short-term $\left.\mathrm{O}_{3}\right)$ are assumed to be constant over the one-year pulse and then drop to zero instantaneously; whereas, the long-term components $\left(\mathrm{CH}_{4}\right.$ and long-term $\left.\mathrm{O}_{3}\right)$ respond and decay with the multimodel mean $\mathrm{CH}_{4}$ perturbation lifetime (11.65 years). For the $20 \% \mathrm{CH}_{4}$ reduction (SR2), an analytical expression is used to calculate the impact of a one-year emissions pulse and subsequent decay [Collins et al., 2010]. This $\mathrm{CH}_{4}$ perturbation is used to scale the $\mathrm{SO}_{4}^{2-}$ and $\mathrm{O}_{3} \mathrm{RFs}$ from SR2 in Figure 7. The formula by Ramaswamy et al. [2001] is used to calculate the $\mathrm{CH}_{4} \mathrm{RF}$.

[36] $\mathrm{GWP}_{\mathrm{H}}$ is given by the RF integrated out to a time horizon $H$ and normalized by the change in emissions, divided by the equivalent for $\mathrm{CO}_{2}$. In Figure 10, and Table S2 in auxiliary material Text S1, we present GWPs for the 20- and 100-year time horizons $\left(\mathrm{GWP}_{20}\right.$ and $\left.\mathrm{GWP}_{100}\right)$. The uncertainties are dominated by the variation in $\mathrm{CH}_{4}$ response across the CTMs. For $\mathrm{NO}_{\mathrm{x}}$ emissions, this uncertainty is sufficiently large that it is not possible to identify the sign of the GWPs. The patterns of GWP ${ }_{100}$ are very similar to the normalized forcings in Figure $7 \mathrm{~b}$ (the patterns would be identical for $\mathrm{GWP}_{\infty}$ ), whereas the $\mathrm{GWP}_{20}$ patterns give more emphasis to short-lived $\mathrm{O}_{3}$ and $\mathrm{SO}_{4}^{2-}$ than $\mathrm{GWP}_{100}$. For $\mathrm{NO}_{\mathrm{x}}$ emissions, this brings $\mathrm{GWP}_{20}$ proportionally closer to zero.

[37] For $\mathrm{NO}_{\mathrm{x}}$ reductions, the $\mathrm{GWP}_{100}$ estimates are similar to those of Forster et al. [2007] and Fuglestvedt et al. [2010], though substantially smaller than those provided by Shindell et al. [2009]. The $\mathrm{O}_{3}$ contribution from Asian $\mathrm{NO}_{\mathrm{x}}$ found by Berntsen et al. [2005] is within the range of the HTAP CTMs' results, but slightly higher than the HTAP multimodel mean. We neglect RFs of nitrate aerosols, but Bauer et al. [2007] suggest nitrate contributions to $\mathrm{NO}_{\mathrm{x}}$ GWPs on the order of -80 for $\mathrm{GWP}_{20}$ and -20 for $\mathrm{GWP}_{100}$. The NMVOC GWPs (Figure 10) are generally smaller than those of Collins et al. [2002]; however, Collins et al. [2002] covered a range of individual NMVOCs. For CO, the GWPs are comparable to those of Derwent et al. [2001], but smaller than those of Berntsen et al. [2005], largely due to the lower $\mathrm{O}_{3}$ response of the HTAP multimodel mean; the $\mathrm{O}_{3}$ response to Asian CO emissions of Berntsen et al. [2005], however, is within the range of the HTAP CTMs. The CO GWP 100 estimates are also smaller than the no-aerosol results of Shindell et al. [2009], due to a lower $\mathrm{CH}_{4}$ response. The $\mathrm{O}_{3}$ contribution to $\mathrm{GWP}_{100}$ for $\mathrm{CH}_{4}$ is smaller in this multimodel study (21\% of the direct $\mathrm{CH}_{4}$ contribution) than the $25 \%$ assumed by Forster et al. [2007], mostly because changes in $\mathrm{O}_{3}$ above the tropopause are neglected. Adding in the contribution of $\mathrm{O}_{3}$ in the lower stratosphere $(15 \%$ of $\mathrm{O}_{3} \mathrm{RF}$ ) [Søvde et al., 2011], and that for stratospheric water vapor $\left(15 \%\right.$ of the $\mathrm{CH}_{4}$ contribution) would give a total $\mathrm{GWP}_{100}$ for $\mathrm{CH}_{4}$ of $24.2 \pm 4.2$.

[38] For $\mathrm{NO}_{\mathrm{x}}$ and NMVOCs, SA emissions have a larger impact than emissions from the other regions. This suggests that some latitudinal dependence may be appropriate for GWPs of $\mathrm{O}_{3}$ precursors. Note that equatorial or $\mathrm{SH}$ emission changes were not considered in this study, but Fuglestvedt et al. [2010] found a dependence on latitude. European $\mathrm{NO}_{\mathrm{x}}$ emissions have a more negative GWP than other regions in the northern midlatitudes, as $\mathrm{O}_{3}$ production in this $\mathrm{NO}_{\mathrm{x}}$-saturated region is lower.

\section{Conclusions}

[39] We quantify the magnitude and distribution of global net $\mathrm{RF}$ due to changes in $\mathrm{O}_{3}, \mathrm{CH}_{4}$, and $\mathrm{SO}_{4}^{2-}$ for $20 \%$ reductions in global $\mathrm{CH}_{4}$ and regional $\mathrm{NO}_{\mathrm{x}}, \mathrm{NMVOC}, \mathrm{CO}$, and combined precursor emissions. We find that the $20 \%$ $\mathrm{NO}_{\mathrm{x}}$ reductions produce global, annually averaged positive net RFs, as positive $\mathrm{CH}_{4} \mathrm{RFs}$ outweigh negative $\mathrm{O}_{3} \mathrm{RFs}$, consistent with previous studies [Fuglestvedt et al., 1999; Wild et al., 2001; Naik et al., 2005; West et al., 2007]. For $\mathrm{CH}_{4}, \mathrm{NMVOC}$, and $\mathrm{CO}$ reductions, $\mathrm{O}_{3}$ and $\mathrm{CH}_{4} \mathrm{RFs}$ are synergistic, yielding overall negative net RFs, consistent with previous global-scale studies [Fiore et al., 2002; West et al., 2007; Shindell et al., 2009]. Including the effects of $\mathrm{O}_{3}$ on plant growth and the carbon cycle may change the sign of net $\mathrm{RF}$ for $\mathrm{NO}_{\mathrm{x}}$ reductions to an overall net climate cooling, in contrast to previous results that neglect this effect, while reinforcing the negative net RFs due to NMVOC and CO reductions, but future research is needed to better quantify this effect.

[40] By normalizing the net RF estimates by changes in emissions (for $\mathrm{NO}_{\mathrm{x}}, \mathrm{NMVOC}$, and $\mathrm{CO}$ ), we find that $\mathrm{RF}$ is more sensitive to $\mathrm{NO}_{\mathrm{x}}$ and NMVOC emission reductions from regions closer to the equator (i.e., SA), consistent with our findings that changes in $\mathrm{O}_{3}$ burden per change in emissions (full troposphere and $\mathrm{UT} \mathrm{O}_{3}$ for $\mathrm{NO}_{\mathrm{x}}$, and $\mathrm{UT} \mathrm{O}_{3}$ for NMVOC) are greatest for SA reductions. RF is more uniformly sensitive to $\mathrm{CO}$ emission reductions from each of the four regions, which agrees with $\mathrm{O}_{3}$ burden changes per unit $\mathrm{CO}$ being less variable across the four regions. The trends in $\mathrm{GWP}_{100}$ across the four regions, for each precursor, reflect the normalized net RF results. Compared to $\mathrm{GWP}_{100}$, the $\mathrm{GWP}_{20}$ patterns are influenced more by short-term $\mathrm{O}_{3}$ and $\mathrm{SO}_{4}^{2-}$. The large uncertainties in the $\mathrm{NO}_{\mathrm{x}}$ GWP estimates, mainly from the variation in calculated $\mathrm{CH}_{4}$ responses across the CTMs, limit the determination of the sign of $\mathrm{NO}_{\mathrm{x}}$ GWPs. The estimated GWPs for individual regions are from the largest model ensemble that has been analyzed to date, and are broadly comparable to previous studies. 
a)

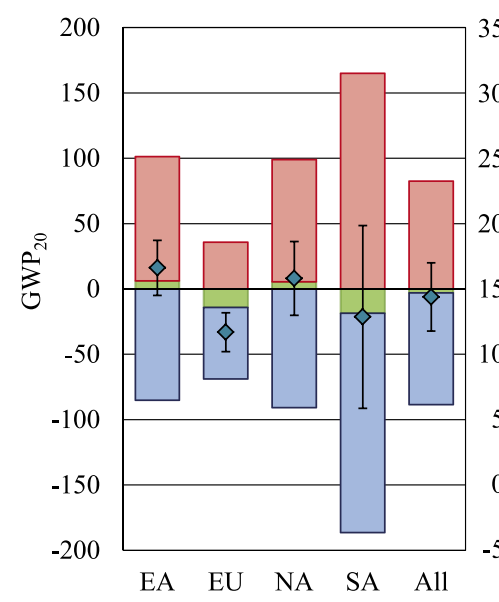

$-20 \% \mathrm{NO}_{\mathrm{x}}$

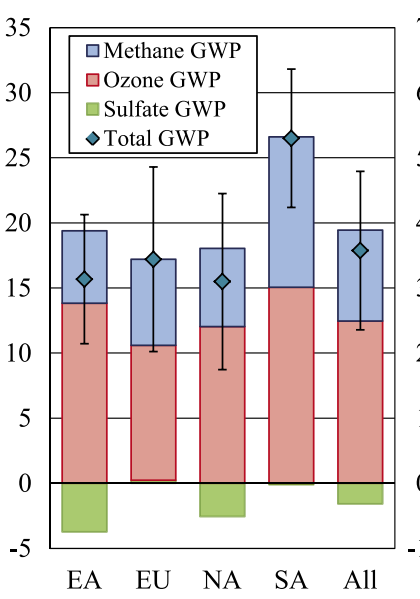

$-20 \%$ NMVOC

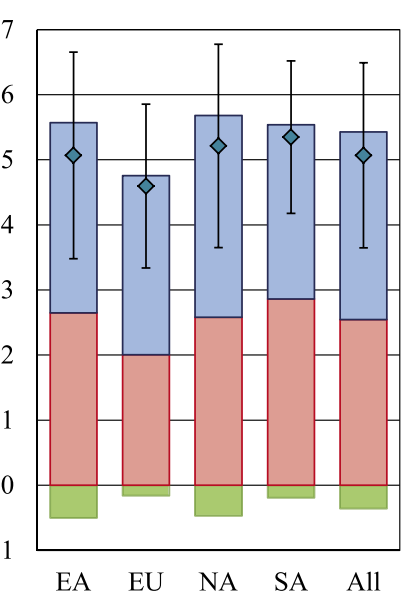

$-20 \% \mathrm{CO}$

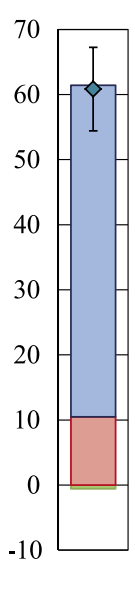

$-20 \% \mathrm{CH}_{4}$

b)

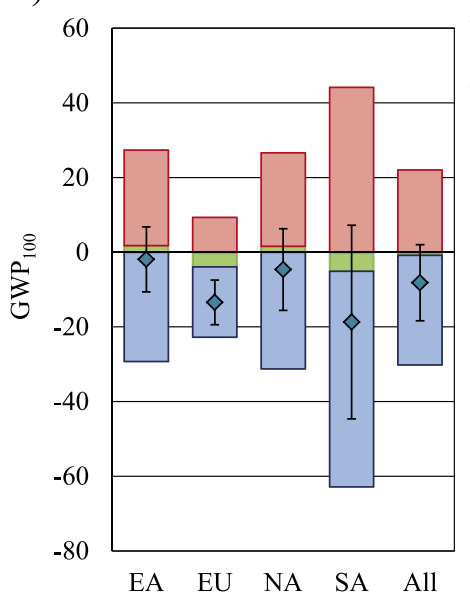

$-20 \% \mathrm{NO}_{\mathrm{x}}$

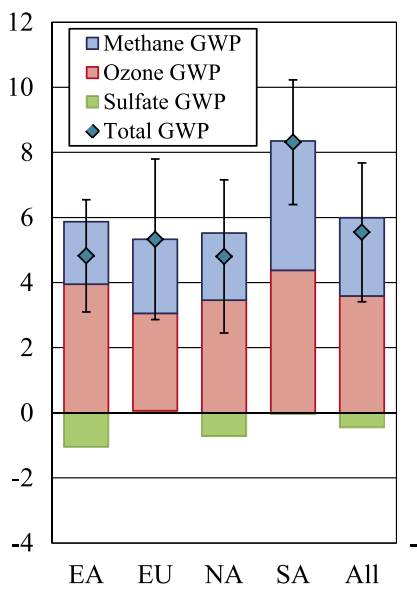

$-20 \%$ NMVOC

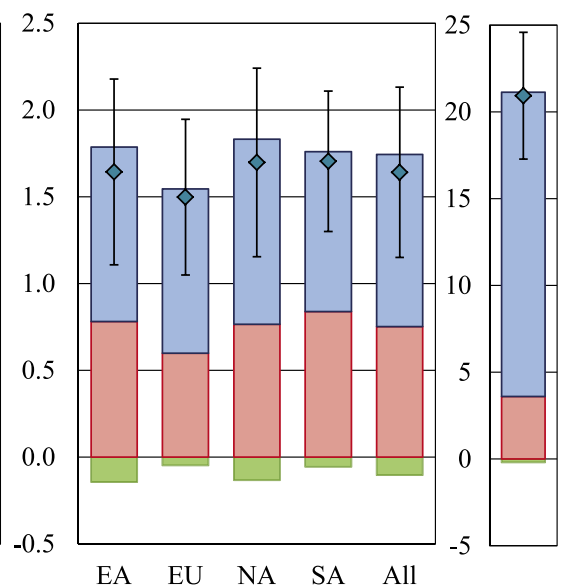

$-20 \% \mathrm{CO}$

$-20 \% \mathrm{CH}_{4}$

Figure 10. GWPs for time horizons of (a) 20 years and (b) 100 years for the $-20 \% \mathrm{CH}_{4}$ burden and $-20 \%$ regional emissions of $\mathrm{NO}_{\mathrm{x}}$, NMVOC, and $\mathrm{CO}$ scenarios. The four regions' estimates (labeled "All") represent the GWP due to the sum of the four regions' responses (to $\mathrm{O}_{3}, \mathrm{CH}_{4}, \mathrm{SO}_{4}^{2-}$, and all three species [Total GWP]). Uncertainty analysis is as in Figure 7, but also includes the uncertainty in the $\mathrm{CH}_{4}$ lifetimes for the base simulation (SR1) (supporting data available in Table S2 in auxiliary material Text S1).

[41] We find that regional RFs correspond to localized increases and decreases in $\mathrm{SO}_{4}^{2-}$ burden. $\mathrm{O}_{3}$ changes are most important for $\mathrm{RF}$ on the regional to hemispheric scales, and $\mathrm{CH}_{4}$ influences RF globally, dominating the $\mathrm{RF}$ response in the $\mathrm{SH}$. The estimated contribution of $\mathrm{SO}_{4}^{2-}$ (direct effect only) to net RF is small compared to the RF of $\mathrm{O}_{3}$ and $\mathrm{CH}_{4}$. Shindell et al. [2009] found with a single $\mathrm{CTM}$ that for global $\mathrm{NO}_{\mathrm{x}}, \mathrm{CO}$, and $\mathrm{VOC}$ emissions, changes in $\mathrm{SO}_{4}^{2-}$ contributed a $\mathrm{RF}$ more comparable in magnitude to the RFs of $\mathrm{O}_{3}$ and $\mathrm{CH}_{4}$. Our findings contrast with those of Shindell et al. [2009] on the importance of $\mathrm{SO}_{4}^{2-} \mathrm{RF}$ due to $\mathrm{O}_{3}$ precursors. However, the robustness of these results is limited, since there was substantial variability in
$\mathrm{SO}_{4}^{2-}$ among only four HTAP CTMs. The effects of $\mathrm{O}_{3}$ precursors on $\mathrm{SO}_{4}^{2-}$ via oxidants merit further research, using newer models that include improved treatment of oxidant-aerosol interactions.

[42] We account for variability in $\mathrm{O}_{3}, \mathrm{CH}_{4}$, and $\mathrm{SO}_{4}^{2-}$ across the ensemble of CTMs, but our estimates of uncertainty only include the variability in CTMs, using a single RTM for all RF estimates. We therefore understate the uncertainty in net RF. In addition, while we capture the most important forcings, a more complete analysis of RF could include RFs due to changes in nitrate aerosols (likely important for $\mathrm{NO}_{\mathrm{x}}$ reductions), the indirect effect of aerosols, internal mixing of aerosols, changes in stratospheric $\mathrm{O}_{3}$ 
and water vapor, and changes to the carbon cycle via nitrogen deposition. Finally, we estimate RF due to changes in the radiative budget of the global atmosphere, but do not estimate the full climate response to regional forcings. Future research should link global and regional RF to climate responses.

[43] Our analysis contributes to the understanding of the effects of $\mathrm{O}_{3}$ precursors on global and regional $\mathrm{RF}$, and provides motivation for evaluating the climate benefits of policies addressing tropospheric $\mathrm{O}_{3}$ and its precursors. We show that among short-lived $\mathrm{O}_{3}$ precursors, NMVOC and $\mathrm{CO}$ emission reductions most effectively reduce RF. Our GWP estimates could form the basis for regionally specific GWPs (or comparable metrics), which may allow $\mathrm{O}_{3}$ precursors to be included in future climate agreements and emissions trading schemes, as well as provide information that could be used to estimate the influence of national or regional policies. Variability in GWPs among regions for $\mathrm{NO}_{x}$ and NMVOCs suggests that regionally specific estimates would be important. For $\mathrm{CO}$, the consistency in RF per unit emissions and $\mathrm{GWP}_{100}$ across the four regions implies that the error in using a uniform GWP for CO may be small. However, the RF per unit $\mathrm{CO}$ emissions may differ in other regions not studied here. Future studies should analyze additional source regions, such as near the equator and in the $\mathrm{SH}$, as other precursors show greater sensitivity in these regions [e.g., Naik et al., 2005].

[44] Acknowledgments. The research described in this paper has been funded wholly or in part by the United States Environmental Protection Agency (EPA) under the Science to Achieve Results (STAR) Graduate Fellowship Program (to M.M. Fry), by the EPA Office of Air Quality Planning and Standards, and by a UNC Junior Faculty Development award (to J.J. West). EPA has not officially endorsed this publication, and the views expressed herein may not reflect the views of the EPA. W.J. Collins was supported by the Joint DECC/Defra Met Office Hadley Centre Climate Programme (GA01101) and Defra contract AQ0902. We thank those involved in the CTM simulations performed under the UN ECE Task Force on Hemispheric Transport of Air Pollution. The NOAA Geophysical Fluid Dynamics Laboratory provided the necessary computational resources.

\section{References}

Barth, M. C., P. J. Rasch, J. T. Kiehl, C. M. Benkovitz, and S. E. Schwartz (2000), Sulfur chemistry in the National Center for Atmospheric Research Community Climate Model: Description, evaluation, features, and sensitivity to aqueous chemistry, J. Geophys. Res., 105(D1), 1387-1415, doi:10.1029/1999JD900773.

Bauer, S. E., D. Koch, N. Unger, S. M. Metzger, D. T. Shindell, and D. G. Streets (2007), Nitrate aerosols today and in 2030: A global simulation including aerosols and tropospheric ozone, Atmos. Chem. Phys., 7, 5043-5059, doi:10.5194/acp-7-5043-2007.

Berntsen, T. K., J. S. Fuglestvedt, M. M. Joshi, K. P. Shine, N. Stuber, M. Ponater, R. Sausen, D. A. Hauglustaine, and L. Li (2005), Response of climate to regional emissions of ozone precursors: Sensitivities and warming potentials, Tellus, Ser. B, 57, 283-304, doi:10.1111/j.16000889.2005.00152.x.

Carlton, A. G., R. W. Pinder, P. V. Bhave, and G. A. Pouliot (2010), To what extent can biogenic SOA be controlled, Environ. Sci. Technol., 44, 3376-3380, doi:10.1021/es903506b.

Collins, W. J., R. G. Derwent, C. E. Johnson, and D. S. Stevenson (2002), The oxidation of organic compounds in the troposphere and their global warming potentials, Clim. Change, 52, 453-479, doi:10.1023/ A: 1014221225434 .

Collins, W. J., S. Sitch, and O. Boucher (2010), How vegetation impacts affect climate metrics for ozone precursors, J. Geophys. Res., 115, D23308, doi:10.1029/2010JD014187.

Dentener, F., D. Stevenson, J. Cofala, R. Mechler, M. Amann, P. Bergamaschi, F. Raes, and R. Derwent (2005), The impact of air pollutant and methane emission controls on tropospheric ozone and radiative forcing: CTM calculations for the period 1990-2030, Atmos. Chem. Phys., 5, 1731-1755, doi:10.5194/acp-5-1731-2005.

Derwent, R. G., W. J. Collins, C. E. Johnson, and D. S. Stevenson (2001), Transient behaviour of tropospheric ozone precursors in a global 3-D CTM and their indirect greenhouse effects, Clim. Change, 49, 463-487, doi:10.1023/A:1010648913655.

Derwent, R. G., D. S. Stevenson, R. M. Doherty, W. J. Collins, M. G. Sanderson, and C. E. Johnson (2008), Radiative forcing from surface $\mathrm{NO}_{\mathrm{x}}$ emissions: Spatial and seasonal variations, Clim. Change, 88 , 385-401, doi:10.1007/s10584-007-9383-8.

Duce, R. A., et al. (2008), Impacts of atmospheric anthropogenic nitrogen on open ocean, Science, 320, 893-897, doi:10.1126/science.1150369.

Felzer, B. S., T. Cronin, J. M. Reilly, J. M. Melilloa, and X. D. Wang (2007), Impacts of ozone on trees and crops, C. R. Geosci., 339, 784-798, doi:10.1016/j.crte.2007.08.008.

Fiore, A. M., D. J. Jacob, B. D. Field, D. G. Streets, S. D. Fernandes, and C. Jang (2002), Linking ozone pollution and climate change: The case for controlling methane, Geophys. Res. Lett., 29(19), 1919, doi:10.1029/ 2002GL015601.

Fiore, A. M., J. J. West, L. W. Horowitz, V. Naik, and M. D. Schwarzkopf (2008), Characterizing the tropospheric ozone response to methane emission controls and the benefits to climate and air quality, J. Geophys. Res., 113, D08307, doi:10.1029/2007JD009162.

Fiore, A. M., et al. (2009), Multimodel estimates of intercontinental sourcereceptor relationships for ozone pollution, J. Geophys. Res., 114, D04301, doi:10.1029/2008JD010816.

Forster, P. M. D., and K. P. Shine (1997), Radiative forcing and temperature trends from stratospheric ozone changes, J. Geophys. Res., 102, 10,841-10,855, doi:10.1029/96JD03510.

Forster, P., et al. (2007), Changes in atmospheric constituents and in radiative forcing, in Climate Change 2007: The Physical Science Basis. Contribution of Working Group I to the Fourth Assessment Report of the Intergovernmental Panel on Climate Change, edited by S. Solomon et al., pp. 129-234, Cambridge Univ. Press, Cambridge, U. K.

Fuglestvedt, J. S., T. K. Berntsen, I. S. A. Isaksen, H. T. Mao, X. Z. Liang, and W. C. Wang (1999), Climatic forcing of nitrogen oxides through changes in tropospheric ozone and methane; global 3D model studies, Atmos. Environ., 33, 961-977, doi:10.1016/S1352-2310(98)00217-9.

Fuglestvedt, J. S., K. P. Shine, T. Berntsen, J. Cook, D. S. Lee, A. Stenke, R. B. Skeie, G. J. M. Velders, and I. A. Waitz (2010), Transport impacts on atmosphere and climate: Metrics, Atmos. Environ., 44, 4648-4677, doi:10.1016/j.atmosenv.2009.04.044.

GFDL Global Atmospheric Model Development Team (GFDL GAMDT) (2004), The new GFDL global atmosphere and land model AM2-LM2: Evaluation with prescribed SST simulations, J. Clim., 17, 4641-4673, doi: $10.1175 /$ JCLI-3223.1.

Granier, C., et al. (2011), Evolution of anthropogenic and biomass burning emissions of air pollutants at global and regional scales during the 1980-2010 period, J. Clim., 109, 163-190, doi:10.1007/s10584-0110154-1.

Hauglustaine, D. A., and G. P. Brasseur (2001), Evolution of tropospheric ozone under anthropogenic activities and associated radiative forcing of climate, J. Geophys. Res., 106, 32,337-32,360, doi:10.1029/ 2001JD900175.

Holland, E. A., and J.-F. Lamarque (1997), Modeling bio-atmospheric coupling of the nitrogen cycle through $\mathrm{NO}_{\mathrm{x}}$ emissions and $\mathrm{NO}_{\mathrm{y}}$ deposi-
tion, Nutr. Cycl. Agroecosyst., 48, 7-24, doi:10.1023/A:1009710122179.

Horowitz, L. W., et al. (2003), A global simulation of tropospheric ozone and related tracers: Description and evaluation of MOZART, version 2, J. Geophys. Res., 108(D24), 4784, doi:10.1029/2002JD002853.

Houweling, S., F. Dentener, and J. Lelieveld (1998), The impact of nonmethane hydrocarbon compounds on tropospheric photochemistry, J. Geophys. Res., 103(D9), 10,673-10,696, doi:10.1029/97JD03582.

Jeuken, A., H. J. Eskes, P. F. J. van Velthoven, H. M. Kelder, and E. V. Holm (1999), Assimilation of total ozone satellite measurements in a three-dimensional tracer transport model, J. Geophys. Res., 104(D5), 5551-5563, doi:10.1029/1998JD100052.

Jeuken, A., J. P. Veefkind, F. Dentener, S. Metzger, and C. R. Gonzalez (2001), Simulation of the aerosol optical depth over Europe for August 1997 and a comparison with observations, J. Geophys. Res., 106, 28,295-28,311, doi:10.1029/2001JD900063.

Jonson, J. E., et al. (2010), A multi-model analysis of vertical ozone profiles, Atmos. Chem. Phys., 9, 26,095-26,142, doi:10.5194/acp-105759-2010.

Kunhikrishnan, T., M. G. Lawrence, R. von Kuhlmann, A. Richter, A. Ladstatter-Weissenmayer, and J. P. Burrows (2004), Analysis of tropospheric $\mathrm{NO}_{\mathrm{x}}$ over Asia using the model of atmospheric transport and chemistry (MATCH-MPIC) and GOME-satellite observations, Atmos. Environ., 38, 581-596, doi:10.1016/j.atmosenv.2003.09.074. 
Lacis, A. A., D. J. Wuebbles, and J. A. Logan (1990), Radiative forcing of climate by changes in the vertical distribution of ozone, J. Geophys. Res. 95, 9971-9981, doi:10.1029/JD095iD07p09971.

Leibensperger, E. M., L. J. Mickley, D. J. Jacob, and S. R. H. Barrett (2011), Intercontinental influence of $\mathrm{NO}_{\mathrm{x}}$ and $\mathrm{CO}$ emissions on particulate matter air quality, Atmos. Environ., 45, 3318-3324, doi:10.1016/j. atmosenv.2011.02.023.

Levy, H., M. D. Schwarzkopf, L. Horowitz, V. Ramaswamy, and K. L. Findell (2008), Strong sensitivity of late 21 st century climate to projected changes in short-lived air pollutants, J. Geophys. Res., 113, D06102, doi:10.1029/2007JD009176.

Meinshausen, M., et al. (2011), The RCP greenhouse gas concentrations and their extension from 1765 to 2300, Clim. Change, 109, 213-241, doi:10.1007/s10584-011-0156-z.

Ming, Y., V. Ramaswamy, P. A. Ginoux, and L. H. Horowitz (2005), Direct radiative forcing of anthropogenic organic aerosol, J. Geophys. Res., 110, D20208, doi:10.1029/2004JD005573.

Naik, V., D. Mauzerall, L. Horowitz, M. D. Schwarzkopf, V. Ramaswamy, and M. Oppenheimer (2005), Net radiative forcing due to changes in regional emissions of tropospheric ozone precursors, J. Geophys. Res. 110, D24306, doi:10.1029/2005JD005908.

Naik, V., D. L. Mauzerall, L. W. Horowitz, M. D. Schwarzkopf, V. Ramaswamy, and M. Oppenheimer (2007), On the sensitivity of radiative forcing from biomass burning aerosols and ozone to emission location, Geophys. Res. Lett., 34, L03818, doi:10.1029/ 2006GL028149.

Park, J. H., M. K. W. Ko, C. H. Jackman, R. A. Plumb, J. A. Kaye, and K. H. Sage (Eds.) (1999), M\&M-2, NASA: Models and Measurements Intercomparison II, NASA Tech. Memo, NASA TM-1999-209554, 502 pp.

Pham, M., J. F. Muller, G. P. Brasseur, C. Granier, and G. Megie (1995), A three-dimensional study of the tropospheric sulfur cycle, J. Geophys. Res., 100(D12), 26,061-26,092, doi:10.1029/95JD02095.

Prather, M. J. (1996), Time scales in atmospheric chemistry: Theory, GWPs for $\mathrm{CH}_{4}$ and $\mathrm{CO}$, and runaway growth, Geophys. Res. Lett., 23 , 2597-2600, doi:10.1029/96GL02371.

Ramaswamy, V., et al. (2001), Radiative forcing of climate change, in Climate Change 2001: The Scientific Basis. Contribution of Working Group I to the Third Assessment Report of the Intergovernmental Panel on Climate Change, edited by J. T. Houghton et al., pp. 349-416, Cambridge Univ. Press, Cambridge, U. K.

Rasch, P. J., M. C. Barth, J. T. Kiehl, S. E. Schwartz, and C. M. Benkovitz (2000), A description of the global sulfur cycle and its controlling processes in the National Center for Atmospheric Research Community Climate Model, Version 3, J. Geophys. Res., 105(D1), 1367-1385, doi:10.1029/1999JD900777.

Reidmiller, D. R., et al. (2009), The influence of foreign vs. North American emissions on surface ozone in the US, Atmos. Chem. Phys., 9, 5027-5042, doi:10.5194/acp-9-5027-2009.

Rotman, D. A., et al. (2004), IMPACT, the LLNL 3-D global atmospheric chemical transport model for the combined troposphere and stratosphere: Model description and analysis of ozone and other trace gases, J. Geophys. Res., 109, D04303, doi:10.1029/2002JD003155.

Rypdal, K., T. Berntsen, J. S. Fuglestvedt, K. Aunan, A. Torvanger, F. Stordal, J. M. Pacyna, and L. P. Nygaard (2005), Tropospheric ozone and aerosols in climate agreements: Scientific and political challenges, Environ. Sci. Policy, 8, 29-43, doi:10.1016/j.envsci.2004.09.003.

Saikawa, E., V. Naik, L. W. Horowitz, J. F. Liu, and D. L. Mauzerall (2009), Present and potential future contributions of sulfate, black and organic carbon aerosols from China to global air quality, premature mortality and radiative forcing, Atmos. Environ., 43, 2814-2822, doi:10.1016/j.atmosenv.2009.02.017.

Sanderson, M. G., et al. (2008), A multi-model study of the hemispheric transport and deposition of oxidized nitrogen, Geophys. Res. Lett., 35, L17815, doi:10.1029/2008GL035389.

Schwarzkopf, M. D., and V. Ramaswamy (1999), Radiative effects of $\mathrm{CH}_{4}, \mathrm{~N}_{2} \mathrm{O}$, halocarbons and the foreign-broadened $\mathrm{H}_{2} \mathrm{O}$ continuum: A GCM experiment, J. Geophys. Res., 104, 9467-9488, doi:10.1029/ 1999JD900003.

Seinfeld, J. H., and S. N. Pandis (2006), Atmospheric Chemistry and Physics - From Air Pollution to Climate Change, 2nd ed., John Wiley, Hoboken, N. J.

Shindell, D., and G. Faluvegi (2009), Climate response to regional radiative forcing during the twentieth century, Nat. Geosci., 2, 294-300, doi:10.1038/ngeo473.

Shindell, D. T., G. Faluvegi, N. Bell, and G. A. Schmidt (2005), An emissions-based view of climate forcing by methane and tropospheric ozone, Geophys. Res. Lett., 32, L04803, doi:10.1029/2004GL021900.
Shindell, D. T., et al. (2008), A multi-model assessment of pollution transport to the Arctic, Atmos. Chem. Phys., 8, 5353-5372, doi:10.5194/acp-85353-2008

Shindell, D. T., G. Faluvegi, D. M. Koch, G. A. Schmidt, N. Unger, and S. E. Bauer (2009), Improved attribution of climate forcing to emissions, Science, 326, 716-718, doi:10.1126/science.1174760.

Shindell, D. T., M. Schulz, Y. Ming, T. Takemura, G. Faluvegi, and V. Ramaswamy (2010), Spatial scales of climate response to inhomogeneous radiative forcing, J. Geophys. Res., 115, D19110, doi:10.1029/ 2010JD014108.

Shine, K. P., J. S. Fuglestvedt, K. Hailemariam, and N. Stuber (2005), Alternatives to the global warming potential for comparing climate impacts of emissions of greenhouse gases, Clim. Change, 68, 281-302, doi:10.1007/s10584-005-1146-9.

Shine, K. P., T. K. Berntsen, J. S. Fuglestvedt, R. B. Skeie, and N. Stuber (2007), Comparing the climate effect of emissions of short- and longlived climate agents, Philos. Trans. R. Soc. A, 365, 1903-1914, doi:10.1098/rsta.2007.2050

Sitch, S., P. M. Cox, W. J. Collins, and C. Huntingford (2007), Indirect radiative forcing of climate change through ozone effects on the landcarbon sink, Nature, 448, 791-794, doi:10.1038/nature06059.

Søvde, O. A., C. R. Hoyle, G. Myhre, and I. S. A. Isaksen (2011), The $\mathrm{HNO}_{3}$ forming branch of the $\mathrm{HO}_{2}+\mathrm{NO}$ reaction: Pre-industrial-to-present trends in atmospheric species and radiative forcings, Atmos. Chem. Phys. 11, 8929-8943, doi:10.5194/acp-11-8929-2011.

Task Force on Hemispheric Transport of Air Pollution (2010), Hemispheric Transport of Air Pollution, U. N. Econ. Comm. for Europe, Geneva, Switzerland

Tie, X. X., S. Madronich, S. Walters, D. P. Edwards, P. Ginoux, N. Mahowald, R. Y. Zhang, C. Lou, and G. Brasseur (2005), Assessment of the global impact of aerosols on tropospheric oxidants, J. Geophys. Res., 110, D03204, doi:10.1029/2004JD005359.

Unger, N., D. T. Shindell, D. M. Koch, and D. G. Streets (2006), Cross influences of ozone and sulfate precursor emissions changes on air quality and climate, Proc. Natl. Acad. Sci. U. S. A., 103(12), 4377-4380, doi:10.1073/pnas.0508769103.

Wang, W. C., Y. C. Zhuang, and R. D. Bojkov (1993), Climatic implications of observed changes in ozone vertical distribution in the middle and high latitudes of the Northern Hemisphere, Geophys. Res. Lett., 20, 1567-1570, doi:10.1029/93GL01318.

West, J. J., A. M. Fiore, V. Naik, L. W. Horowitz, M. D. Schwarzkopf, and D. L. Mauzerall (2007), Ozone air quality and radiative forcing consequences of changes in ozone precursor emissions, Geophys. Res. Lett., 34, L06806, doi:10.1029/2006GL029173.

West, J. J., V. Naik, L. W. Horowitz, and A. M. Fiore (2009a), Effect of regional precursor emission controls on long-range ozone transport-Part 1: Short-term changes in ozone air quality, Atmos. Chem. Phys., 9, 6077-6093, doi:10.5194/acp-9-6077-2009.

West, J. J., V. Naik, L. W. Horowitz, and A. M. Fiore (2009b), Effect of regional precursor emission controls on long-range ozone transport-Part 2: Steady-state changes in ozone air quality and impacts on human mortality, Atmos. Chem. Phys., 9, 6095-6107, doi:10.5194/ acp-9-6095-2009

Wild, O., M. J. Prather, and H. Akimoto (2001), Indirect long-term global radiative cooling from $\mathrm{NO}_{\mathrm{x}}$ emissions, Geophys. Res. Lett., 28(9), 1719-1722, doi:10.1029/2000GL012573

C. Atherton, Gordon and Betty Moore Foundation, 1661 Page Mill Rd., Palo Alto, CA 94304, USA.

D. Bergmann, Atmospheric Earth and Energy Division, Lawrence Livermore National Laboratory, 7000 East Ave., Livermore, CA 94550, USA. W. J. Collins, Met Office Hadley Centre, FitzRoy Road, Exeter EX1 3PB, UK

F. J. Dentener, Institute for Environment and Sustainability, DG-Joint Research Centre, European Commission, TP 280, I-21020 Ispra, Italy.

B. N. Duncan, NASA Goddard Space Flight Center, Greenbelt, MD 20771, USA.

A. M. Fiore, Lamont-Doherty Earth Observatory, 61 Rte. 9W, Palisades, NY, 10964 USA.

M. M. Fry and J. J. West, Department of Environmental Sciences and Engineering, University of North Carolina at Chapel Hill, 146B Rosenau Hall, CB 7431, Chapel Hill, NC 27599, USA. (jasonwest@unc.edu)

P. Hess, Biological and Environmental Engineering, Cornell University, 312 Riley-Robb Hall, Ithaca, NY 14850, USA.

I. A. MacKenzie, School of GeoSciences, University of Edinburgh, King's Buildings, West Mains Road, Edinburgh EH9 3JN, UK.

E. Marmer, Department of Geography, University of Hamburg, Grindelberg 7, 2012, D-20144 Hamburg, Germany. 
V. Naik, Atmospheric Physics, Chemistry, and Climate Group, UCAR GFDL, 201 Forrestal Rd., Princeton, NJ 08540, USA.

M. G. Schultz, Institut für Energie- und Klimaforschung (IEK-8), Forschungszentrum Jülich GmbH, D-52425 Jülich, Germany.

M. D. Schwarzkopf, Atmospheric Physics, Chemistry, and Climate Group, NOAA GFDL, 201 Forrestal Rd., Princeton, NJ 08540, USA.

D. T. Shindell, NASA Goddard Institute for Space Studies, 2880 Broadway, New York, NY 10025, USA.
S. Szopa, Laboratoire des Sciences du Climat et de l'Environnement, CEA, IPSL, UVSQ, CNRS, F-91191 Gif-sur-Yvette, France.

O. Wild, Lancaster Environment Centre, Lancaster University, Lancaster LA1 4YQ, UK

G. Zeng, National Institute of Water and Atmospheric Research, Private Bag 50061, Omakau, Central Otago 9352, New Zealand. 